\title{
BUILDING TRADE-RELATING INSTITUTIONS AND WTO ACCESSION
}

\section{Sudip Ranjan Basu \\ Victor Ognivtsev \\ Miho Shirotori \\ UNCTAD, Geneva}

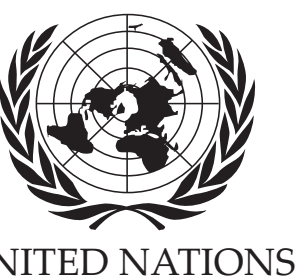

UNITED NATIONS

New York and Geneva, 2009 


\section{NOTE}

The purpose of this series of studies is to analyse policy issues and to stimulate discussions in the area of international trade and development. This series includes studies by UNCTAD staff, as well as by distinguished researchers from academia. In keeping with the objective of the series, authors are encouraged to express their own views, which do not necessarily reflect the views of the United Nations or its member states.

The designations employed and the presentation of the material do not imply the expression of any opinion whatsoever on the part of the United Nations Secretariat concerning the legal status of any country, territory, city or area, or of its authorities, or concerning the delimitation of its frontiers or boundaries.

Material in this publication may be freely quoted or reprinted, but acknowledgement is requested, together with a reference to the document number. It would be appreciated if a copy of the publication containing the quotation or reprint were sent to the UNCTAD secretariat at the following address:

Chief

Trade Analysis Branch

Division on International Trade in Goods and Services, and Commodities

United Nations Conference on Trade and Development

Palais des Nations

CH-1211 Geneva

Series editor:

Victor Ognivtsev

Officer-in-charge, Trade Analysis Branch

DITC/UNCTAD

UNCTAD/ITCD/TAB/42

\begin{tabular}{|c|}
\hline UNITED NATIONS PUBLICATION \\
\hline ISSN 1607-8291 \\
\hline
\end{tabular}

(c) Copyright United Nations 2009

All rights reserved 


\begin{abstract}
The paper aims to examine how trade rules affect a much greater array of domestic policies and institutions than ever before. The expanding scope of trade policy places an additional strain on policymaking and institution-building, especially for developing countries. By analysing WTO accession cases, the paper concludes that this process can, under certain conditions, induce countries to establish or improve trade-related institutions. The difference-in-difference analysis is employed as the empirical model. Results are robust with alternative model specifications and choice of economic policies and institutional variable. However, the accession process lacks mechanisms which take account of acceding countries' differing levels of economic development and institutional capacity, placing a heavier burden of implementation policy and institutional reform and related costs on countries with limited human, administrative and financial resources such as LDCs.
\end{abstract}

Key Words: WTO, Institution, Difference-in-Difference Analysis, LDCs

JEL Classification Numbers: F13, O1, C3 


\section{ACKNOWLEDGEMENTS}

We would like to express our sincere thanks to Lakshmi Puri, Khalil Rahman, Andrew Cornford, Craig Van Grasstek, Aki Kuwahara, John Cuddy, Richard Baldwin, Marc Bacchetta, Jaya Krishnakumar, Patrick Low, Lucian Cernat, Marco Fugazza, Alberto Portugal, Deepali Fernandez, Samuel Munyaneza and Wojciech Stawowy for comments at different stages of the preparation of the paper. Comments from the seminar participants at the Indian Institute of Foreign Trade, New Delhi and at the Graduate Institute, Geneva are also acknowledged. 


\section{CONTENTS}

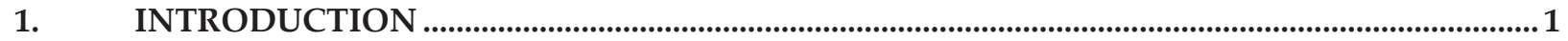

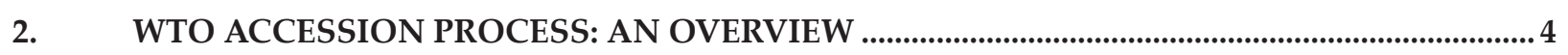

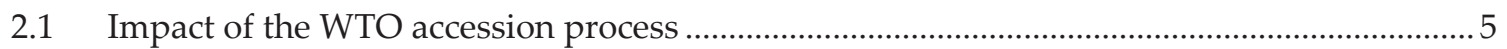

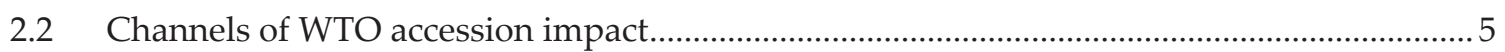

3. MODEL-BASED ANALYSIS OF WTO ACCESSION AND THE

BUILDING OF TRADE-RELATED INSTITUTIONS ...................................................................

3.1 WTO accession: A qualitative analysis of economic conditions .............................................. 10

3.2 WTO accession: A qualitative analysis of policy and institutions ............................................ 11

3.3 WTO accession: A qualitative analysis of terms of accession .............................................. 13

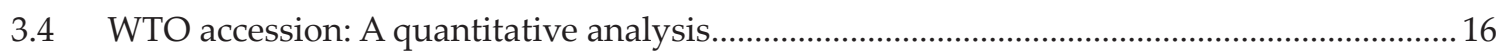

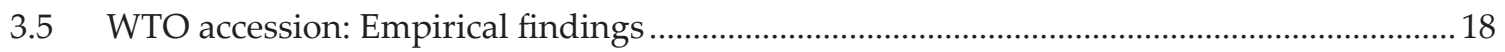

3.6 WTO accession: Robustness checks of empirical findings ..................................................... 20

4. IMPLICATIONS OF ANALYSIS FOR SPECIAL MEASURES

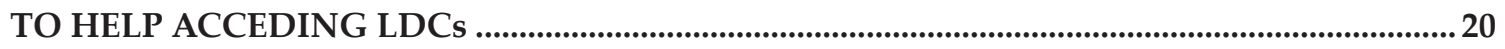

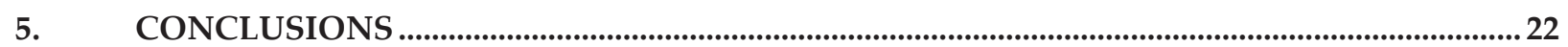

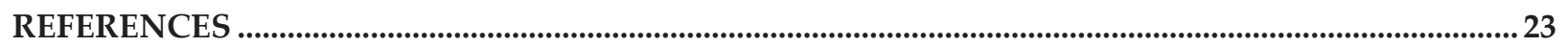




\section{List of Figures}

Figure 1. $\quad$ Linking the terms of accession to (1) GDP per capita and (2) a measure of

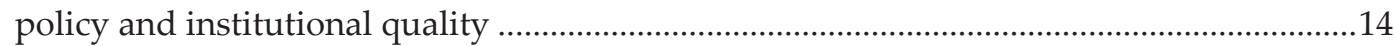

Figure 2. The commitments of acceded members and export share in world trade

\section{List of Tables}

Table 1. Impacts of WTO accession process on economic policies and institutions

Table 2. Illustrative interplay between international institutions (multilateral trade rules)

and national trade-related institutions

Table 3. Depth of commitments in accession agreements

\section{APPENDIX TABLES}

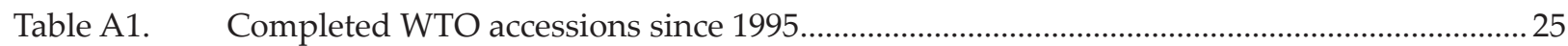

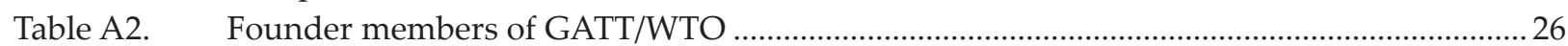

Table A3. Ongoing accessions to the WTO (updated 14 February 2008) ................................................2 27

Table A4. Population, GDP per capita and Trade/GDP of 23 newly acceded WTO members ............. 28

Table A5. Shares of merchandise exports and imports of 23 newly acceded WTO members..............29

Table A6. $\quad$ MFN Tariff Rates (simple average) of 23 newly acceded WTO members.............................. 30

Table A7. Descriptive statistics of 23 newly acceded WTO members ........................................................ 30

Table A8. List of commitments (areas and paragraphs), working party meetings and number of members................................................................. 31

Table A9. Freedom House Index of Economic Freedom (EFI) …………................................................. 32

Table A10. Descriptive statistics of the Index of Economic Freedom (EFI) ................................................. 34

Table A11. PRS Group-International Country Risk Guide (ICRG) ............................................................. 34

Table A12. Descriptive statistics of International Country Risk Guide (ICRG) database ....................... 35

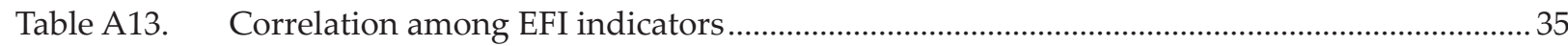

Table A14. Correlation of GDP per capita with EFI indicators ...............................................................

Table A15. Correlation among International Country Risk Guide (ICRG) indicators............................... 36

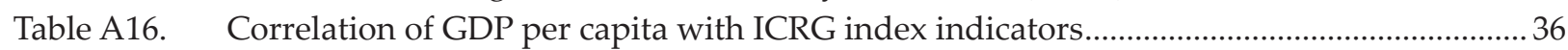

Table A17. List of countries in sample for empirical analysis ..................................................................37

Table A18. OLS estimation - WTO accession impact on domestic economic

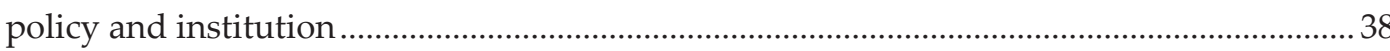

Table A19. FGLS estimation - WTO accession impact on domestic economic

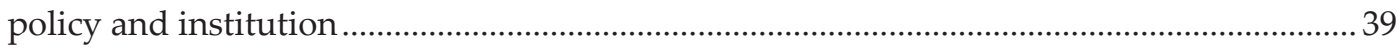

Table A20. Fixed effects estimation - WTO accession impact on domestic economic policy and institution

Table A21. OLS estimation - Robustness analysis: WTO accession impact on domestic economic policy and institution

Table A22. FGLS estimation - Robustness analysis: WTO accession impact on domestic economic policy and institution.

Table A23. Fixed effects estimation - Robustness analysis: WTO accession impact on domestic economic policy and institution

Table A24. Fixed effects - Robustness analysis: WTO accession impact, dropping outlier countries 


\section{INTRODUCTION}

The implications of changing multilateral trading relations for international trade and development are immense. Recent trends in global economic affairs highlight the challenges which developing countries face in their efforts to build effective trade-related institutions. This has provided an impetus to development-oriented international trade and economic integration. In this context, the role of the World Trade Organization (WTO) is crucial in helping countries integrate beneficially into the international trading system. In the current phase of economic globalization, countries are indeed trying to participate in this global economic system to reap the benefits of deepening integration. ${ }^{1}$

The main focus of the analysis is the implications of WTO membership for the development of trade-related institutions such as the laws and regulatory frameworks that govern trade as well as the administrative mechanisms and processes for designing, implementing and evaluating trade and trade-related policies. The effectiveness of these institutions at the national level is crucial in terms of ensuring trade liberalization and guaranteeing benefits from the multilateral trading system.

UNCTAD (2005) discussed how gains from trade liberalization came about in the long run, at least in the absence of externalities, while noting that liberalization could have some serious short- to medium-term adjustment implications for developing countries.

The WTO process can help developing countries successfully adjust by ensuring meaningful liberalization by developed countries in areas where developing countries enjoy a comparative advantage, ahead of liberalization by developing countries themselves, so that new trading opportunities create new jobs in developing countries before possible job losses in sectors that may suffer from increased competition as a result of their own liberalization. The WTO process could also usefully address systemic and

\footnotetext{
1 Frankel (2001) reports that the new round, when dynamic effects are included, 'might raise global income per capita by 2 per cent over a 25 -year period.'
}

rule-related issues in order to provide developing countries with some policy space for the use of trade and trade-related policies for development purposes. This was partly envisaged in theoriginal GATT, but it seems that such options, including the use of support policies in the presence of externalities, are increasingly being called into question. ${ }^{2}$ International trade involves interaction with partner countries so that a country's traderelated institutions cannot be related solely to domestic interests and concerns. The rules that govern domestic trade have to accommodate rules and organizational arrangements that also apply to other actors in the international trading system. Key sources of these rules are various agreements negotiated multilaterally at and administered by WTO and bilateral/regional trade agreements (RTAs), which have been proliferating in recent years and have involved developing countries on all three continents. Those rules that constitute a country's international commitments and obligations have to be reflected in a country's national legislation. ${ }^{3}$

The international trading system today incorporates a much broader range of economic activities, issues, rules, and commitments than the pre-1994 regime of the General Agreement on Tariffs and Trade (GATT) and the preferential trade agreements (PTAs, RTAs, FTAs) which were mostly limited to tariff liberalization. Topics such as investment, environmental protection and intellectual property rights, the international dimensions of which were previously handled through sector- or subject-specific agreements and arrangements, have now been brought within the scope of trade policy. As a result, not only goods but also cross-border movements of services, investment, intellectual property, and even people are now included in the overall trade policy agenda. Moreover, what were once considered non-trade issues such as labour practices, environmental standards and even human rights are now also largely treated by major developed trading countries under this heading.

\footnotetext{
${ }^{2}$ See Chapter 3, DCIT-TDI 2005 for further discussion.

${ }^{3}$ UNCTAD (2008): UNCTAD-JETRO publication.
} 
Since WTO agreements were based on the principle of a single undertaking, all Member States are obliged to be party to all the agreements which cover a wider set of border as well as domestic policy issues than the GATT. ${ }^{4}$ This has reduced the domestic policy space previously available to developing countries.

Thus international trade rules affect a much greater array of domestic policies and regulations than ever before and therefore have an impact on and are impacted by domestic institutions. For instance, multilateral trade agreements involving sanitary and phytosanitary measures, as well as technical barriers to trade, generally require changes in national standardsetting institutions, procedures, and enforcement mechanisms. Existing and proposed WTO rules on agriculture and the provisions concerning labour and environmental issues in some bilateral free trade agreements (FTAs) intrude deeply on domestic social and economic policies.

The expanding scope of trade policy places an additional strain on policymaking and institution-building, especially for developing countries. Countries that once faced simple choices about whether or not to join the GATT must now be prepared to undertake (sometimes simultaneously) negotiations at bilateral, regional, and multilateral levels. One consequence of this is that it is more difficult to verify compliance with the obligations in the trading system. For example, a country's policymaker may be unaware that a new domestic law or regulation is not in compliance with obligations undertaken in one of the more technically complex WTO agreements or FTA chapters. Verification of compliance by trading partners can pose an even greater challenge.

Ideally, WTO membership should reduce the strains on policymaking. First, it is supposed to ensure that members conduct their trade policies transparently according to a common set of agreed

\footnotetext{
These include the Uruguay Round agreements on agriculture, textiles and clothing, trade-related aspects of intellectual property rights (TRIPS), trade-related investment measures (TRIMs), services (GATS), sanitary and phytosanitary standards (SPS), customs valuation and expanded versions of Tokyo Round agreements on technical barriers to trade, import licensing procedures and subsidies/ countervailing measures.
}

rules, thereby reducing transaction costs and risks linked to uncertainty over trade measures of partner countries. Second, and perhaps more importantly for developing countries, undertaking the obligations of WTO membership may help strengthen a country's trade-related institutions. By using these obligations as an external policy anchor or stimulus, policymakers can help streamline regulatory and institutional policies and measures. Also, a country may be able to inject greater coherence into different policies affecting trade. However, the potential benefits have to be weighed against the danger that if the obligations of WTO membership, and, indeed, also of obligations under FTAs, embody a "one-size-fits-all" approach, this would place unsustainable costs - economically, socially and politically in a democratic context-and substantial constraints on a country's policy space.

This paper takes up various issues related to the way in which WTO membership can affect a country's trade-related institution-building. The analysis is based on WTO accession cases in 1995-2007. Findings suggest that WTO accession can, under certain conditions, induce countries to establish or improve trade-related institutions. However, the accession process itself needs to have mechanisms which take account of acceding countries' differing levels of economic development and institutional capacity, so as to avoid placing a heavier burden in terms of implementation policy and institutional reform and related costs on countries with limited human, administrative and financial resources. Furthermore, a country's objectives in joining the WTO are not necessarily limited to membership per se, but are also likely to include exerting an influence on the multilateral trading system (MTS) and its future evolution so as to best promote its trade and development objectives. Yet this depends on the capacity to participate effectively in multilateral rule-making. The final and concluding section contains some suggestions as to the necessary ingredients for building a more effective trade-policy capacity. 
As of 14 February 2008, 23 new members had acceded to WTO, raising total membership to 151 (see Appendix table A1). The hope for these new members is to integrate their national trade into the multilateral trading system so as to gain through economic transactions and trade expansion. ${ }^{5}$ Furthermore, WTO membership is often seen as a means to gain credibility from the international business community; it is thought to reflect the willingness of acceding countries to implement far-reaching changes in domestic economic policies and institutions. ${ }^{6}$

During the negotiation process, the newly acceded members undertook a number of substantive commitments to redesign their domestic economic structure and institutional framework, as well as to make economic conditions more stable and predictable. The accession process is often regarded as an unprecedented exercise in terms of the commitments that link aspects of domestic economic policies and institutional matters. In particular, acceding countries have had to deliver tangible results to bring about changes in trade laws and regulations, providing improved market access in goods and services through reduction of import tariff duties and opening of services sectors and making their trade regimes more transparent for business communities. As noted previously, these substantial domestic economic policy changes were expected to send a credible signal to foreign investors in order to boost their confidence. ${ }^{7}$ Nevertheless, research has not paid

\footnotetext{
5 Those are (in chronological order): Ecuador; Bulgaria; Mongolia; Panama; Kyrgyz Republic; Latvia; Estonia; Jordan; Georgia; Albania; Oman; Croatia; Lithuania; Moldova; China; Chinese Taipei (referred to in the United Nations as Taiwan Province of China); Armenia; Former Yugoslav Republic of Macedonia (FYROM); Nepal; Cambodia; Saudi Arabia; Viet Nam and Kingdom of Tonga. In addition, the WTO General Council on 5 February 2008 paved the way for Ukraine's membership by approving its accession terms. Following the ratification of these terms, Ukraine became the 152nd member of WTO. See http://www.wto.org/english/thewto_e/ acc_e/acc_e.htm

6 North(1993) describes institution as "the process of change", and helps "improving the performance of economies through time". He emphasizes that the key elements of institutions are to "have secure property rights" and "rule of law".

Detken et al (2004) discussed the role of European Union (EU) in helping increase economic and political stability in the newly acceding countries. They noted the overall positive achievements of newly 10 acceded countries in terms of domestic policy reform and institutions, making a strong point for the EU's role as an institutional anchor.
}

much attention to analysing the issues relevant to changes in domestic economic policies and institutions due to the WTO accession process of newly acceded members. ${ }^{8}$

There are important, not to mention, controversial, studies to assess the impact of WTO membership on countries' trade benefits and its role in providing critical impetus to economic activities. ${ }^{9}$ WTO as a rule-making multilateral world body ought to deliver meaningful benefits. However, given the differing levels of economic development and domestic absorption capacity of many acceding countries, adjustment must be country-specific in order to reduce any unwanted costs that might arise during the process. Hence, the analysis of WTO accession should be broadened to include issues related to broader economic policies and institutional structures and dimensions. ${ }^{10}$

The paper is organized as follows: Section 2 outlines the WTO accession process and the channels through which WTO accession can impact economic policy and institutions. Section 3 shows initial results of 23 newly acceded WTO members in terms of GDP per capita, tariff rates, and trade indicators etc. Next, specific results are shown by descriptive statistics on domestic economic policies and institutions and some correlates are explored. The empirical methodology and statistics are described afterwards. We employ difference-indifference analysis to identify the performance of the 'treatment group' (the newly acceded WTO members) in relation to the 'control group'- the GATT/WTO developing countries in the sample. We also carry out a robustness analysis. Section 4 discusses some implications of WTO accession for the LDCs, while Section 5 concludes the paper.

\footnotetext{
8 According to former WTO Director-General M. Moore: "One important way in which countries can demonstrate their commitment to policy stability, predictability and good governance is through membership of WTO". See WTO website for text of entire speech.

9 See Piermartini and Teh (2005) for an overview of key CGE and gravity modelling exercise results from Uruguay Round and Doha Round.

10 See Acemoglu et al (2001), Rodrik et al (2004) for empirical evidence of the role of institutions in economic development.
} 


\section{WTO ACCESSION PROCESS: AN OVERVIEW}

Integration into the multilateral trading system is a major part of the rationale for acceding to the WTO. During the negotiation process, the newly acceded members undertook a number of substantive commitments to redesign their domesticeconomicstructure and legal framework, as well as to make economic conditions more stable and predictable. The accession process is often regarded as an unprecedented exercise in terms of the commitments that link aspects of domestic economic policies and institutional matters. In particular, acceding countries have had to deliver tangible results to bring about changes in trade laws and regulations, providing improved market access in goods and services through the reduction of import tariff duties and the opening-up of services sectors and making their trade regimes more transparent for business communities. As noted previously, these substantial domestic economic policy changes were expected to send a credible signal to foreign investors in order to boost their confidence. ${ }^{11}$ Nevertheless, research has not paid much attention to a systematic examination of the issues relevant to domestic economic policies and institutions due to the WTO accession process of newly acceded members. ${ }^{12}$

Countries should follow some broad steps before becoming WTO members. Article XII of the WTO Agreement states that the conditions to become WTO members are as follows: 'accession to WTO will be "on terms to be agreed" between the acceding government and WTO". ${ }^{13}$ The WTO accession process follows the general rule where "each accession Working Party takes decisions

\footnotetext{
11 Detken et al (2004) discussed the role of the European Union (EU) in helping increase economic and political stability in the newly acceding countries. They noted the overall positive achievements of newly 10 acceded countries in terms of domestic policy reform and institutions, making a strong point for the EU's role as an institutional anchor.

12 According to former WTO Director-General M. Moore: "One important way in which countries can demonstrate their commitment to policy stability, predictability and good governance is through membership of WTO". See WTO website for text of entire speech.

13 See http://www.wto.org/english/thewto_e/acc_e/acces_e. htm
}

by consensus, all interested WTO members must be in agreement that their individual concerns have been met and that outstanding issues have been resolved in the course of their bilateral and multilateral negotiations". ${ }^{14}$

An individual country makes an application for accession negotiation to begin. After this initial process, a Working Party is set up to initiate three interrelated tracks of accession negotiation: a systemic or multilateral track, a market access in goods track and a market access in services track. During the accession process, countries submit detailed questions in the following areas: balance of payments; foreign exchange operations; statistics and publication systems relating to foreign trade; customs import tariffs, including any preferential tariffs, customs fees, tariff exemptions, etc.; export regulations; import licensing; State trading enterprises; pricing practices and regulations; taxation systems; subsidies to specific sectors of the economy, particularly agriculture; foreign investment regime; safeguard measures and other trade remedies (anti-dumping and countervailing measures, standardization and certification of imported goods); sanitary and phytosanitary standards; and systems for the protection of intellectual property rights. ${ }^{15}$ Therefore, WTO members are expected to benefit from participation in the multilateral trading system, as this is expected to raise income, trade, and encourage better government and the rule of law (italics added). ${ }^{16}$

Of the 151 members, 128 were contracting parties of the GATT system. The latter countries became "founder-members" of WTO when it was set up on 1 January 1995 after the signing of the Uruguay Round Agreement at Marrakesh in April 1994 (Appendix table A2 lists founder members of GATT/WTO, while table A3 lists countries with

\footnotetext{
14 See http://www.wto.org/english/thewto_e/acc_e/acces_e. htm for detailed discussion.

15 See UNCTAD (2001), and other WTO accession documents for further discussions.

16 See http://www.wto.org/english/thewto_e/whatis_e/10 ben_e/10b00_e.htm for further discussion.
} 
ongoing accession to WTO). ${ }^{17}$ These 128 founder members did not need to accede to WTO under Article XII.I of the Marrakesh Agreement. ${ }^{18}$

\subsection{Impact of the WTO accession process}

It has been discussed over the years that there is a need to strike an appropriate balance between domestic challenges and conformity with international trade rules during the process of negotiations so as to enhance their increasing and beneficial participation in the multilateral trading system. Accession may foster the following changes in a country: "Accession, if it is to be achieved on balanced terms, should be recognized as a difficult and complicated process, which may be lengthy, requiring high-level preparations and coordination among government agencies and a broad political consensus in order to effectively pursue and defend national interests. It will also require tough negotiations with major WTO members. Such negotiations involve strategic and long-term issues which could affect the trade and development policies of countries concerned for years to come" (UNCTAD 2001).

This section provides the possible mechanismsthrough which WTOaccessionaffects a country's policy and institutions. Membership in WTO requires that a country's trade regime conform to WTO rules. The WTO rules consist of the General Agreement on Tariffs and Trade (GATT), twelve issue-specific agreements (e.g. on agriculture), the General Agreement on Trade in Services (GATS) and the Agreement on Trade-Related Aspects of Intellectual Property Rights (TRIPs). Within a set-up of a multilateral

\footnotetext{
17 Another route to WTO membership is contained in GATT Article XXVI:5(c) of GATT 1947, which notes that a territory of a contracting party that attains autonomy can be sponsored for membership by the contracting party Because of this provision, 18 countries became WTO members in 1994 while Algeria and Cambodia had the possibility to exercise this clause but did not do so. The Article states "If any of the customs territories, in respect of which a contracting party has accepted this Agreement, possesses or acquires full autonomy in the conduct of its external commercial relations and of the other matters provided for in this Agreement, such territory shall, upon sponsorship through a declaration by the responsible contracting party establishing the abovementioned fact, be deemed to be a contracting party". See http://www.wto.org/english/docs_e/legal_e/gatt47_02_e. htm\#articleXXVI.

18 See Ognivtsev et al (UNCTAD, 2001) for a comprehensive discussion on accession issues.
}

"Working Party" on each accession case, WTO members investigate whether any part of the acceding country's trade regime is inconsistent with WTO rules. ${ }^{19}$ Two main areas under the scrutiny are economic policy measures that affect imports and exports, and the institutional framework (of legal and judicial factors) for making and enforcing such policies. Therefore, it is evident from accession requirements that one ought to look into the details of WTO accession for newly acceded members.

\subsection{Channels of WTO accession impact}

WTO accession impacts the domestic economic policies and institutions through a variety of WTO rules, which directly correspond to for example those included under "policies affecting trade in goods and services". The specific economic policy measures in this package include regulations for imports and exports (e.g. tariff types, import licensing system, non-tariff barriers and export tax) as well as other "internal" measures that may affect trade, such as industrial and agricultural subsidies, technical standards, and State trading entities as documented in a WTO accession technical note. If WTO members find that any economic policy measure is inconsistent with certain WTO provision(s), the acceding country needs to provide evidence as to when and how it intends to reform the specific economic policy in question, because these are all part of overall changes of the domestic economy. So, economic policy reforms and institutional changes declared in this manner by an acceding country are regarded as commitments on "rules".

Parallel to multilateral negotiations on rules, an acceding country negotiates bilaterally with interested WTO members over how many "concessions" it should make in terms of opening its market to exports from WTO members. Concessions consist of tariffs that are to be bound at "commercially viable levels" (WTO 1995), so that these concessions are incorporated in the schedule of commitments for the country in the process of accession.

\footnotetext{
19 The largest Working Party so far is on the accession of the Russian Federation, in which fifty-eight WTO members participate. The smallest ones are for Bhutan and Montenegro, each with nine WTO members (WTO 2005, page 8).
} 
Let us now discuss specifically the two main areas affected by WTO accession - economic policy and institution-building. There is no WTO Agreement requiring specific reform and change in many of the so-called institutional indicators, but the broad set of commitments can actually bring about real changes in not only economic policies but also in the institutions of the acceding country. ${ }^{20}$

Once the accession negotiations are over, WTO members and the acceding countries agree on the terms of accession that are made up of the latter's commitments on rules and on market access negotiations. These terms are detailed in the Working Party Report. The Legislative Action Plans (LAPs), which provide a clear indication of institutional changes, contain a timetable for legislative changes, required implementing declared policy reform, and the Schedules of Concessions in Goods and in Services. It is worth noting here that these documents are legally binding under the protocol of accession, i.e. they cannot be altered unilaterally by the acceding country without a priori consultation. All these clearly indicate a potential influence of WTO accession on acceding members' domestic economic policies and institutions.

In the spirit of this paper, we examine the "width" - the areas - of economic policy and institutional changes specified in the terms of accession for 23 countries that have acceded to WTO since 1995 . The width of economic policy changes is assessed in terms of the number of areas where a country stated its commitment on economic policy reform in its Working Party Report. It is worth noting here that the spread of commitments made by each country across different policy areas remains very similar, as it is part of the accession requirement. ${ }^{21}$

\footnotetext{
${ }_{20}$ Quite a number of recently acceded countries made commitments with regard to privatization of State-owned enterprises and pricing policies. Such commitments are referred to as "WTO-plus", as they exceed the level of obligations that applies to existing WTO members.

21 The "Technical Note on Accession Process" (2005), prepared by the WTO secretariat, provides paragraphs which provide a type of commitments in the Working Party Reports of each country. Commitments under this note take different forms, e.g. a specification of national measures to be amended in order to conform to WTO rules, acceptance of obligation to abide by existing WTO rules, or obligation not to have recourse to specific WTO provisions (e.g. transition periods) among others. The WTO secretariat note also indicates the number of paragraphs used to specify each commitment.
}

Across different policy areas, almost all countries made commitments in areas which have a direct correspondence to a WTO Agreement such as anti-dumping, customs valuation, import licensing measures and TRIPs. In such cases, commitments are a simple statement that a country will abide with the given WTO rule, worded in an almost identical manner across countries probably because the previous Working Party Reports were taken as a precedent. Then, contents of the commitments often include specification of laws to be amended or created in order to be consistent and ensure economic policy reform. If countries have no commitment in a policy area, this generally means that they already have a trade regime that conforms to the corresponding WTO rules. In the case of developing countries and particularly LDCs, it could be due to the fact that special and differential (S\&D) provision of a given WTO rule allows them to be exempted from abiding with the rules, though there are cases where the S\&D provisions are not automatically granted to newly acceding countries including LDCs. $^{22}$

In table 1, we schematically report on two areas where a typical working party document for the WTO accession process and WTO membership would impact on domestic economic and institutional aspects. Against the backdrop of the above discussions, economic policy and institutional changes are the two areas of the WTO accession process that we investigate because of the direct links.

We argue that the accession commitments and stringent requirement for making changes in domestic economic policies and institutional framework help aspiring countries implement and deepen their transformation for qualitative change over time. These countries' commitments in the multilateral forum require them to display greater credibility in terms of putting in place appropriate sets of economic policies within the given time period. The time-bound commitments help to generate a huge amount of domestic pressures in place of a WTO-consistent set of

\footnotetext{
22 Note that in some policy areas such as agriculture, making no commitment is a declaration that a country follows the WTO rule. For instance, as regards agricultural policy, no commitment in terms of reduction of agricultural subsidies means that a country is committed not to having any such subsidies to begin with.
} 
Table 1. Impacts of WTO accession process on economic policies and institutions

\begin{tabular}{|c|c|c|c|}
\hline & & & Commitments in specific policy areas \\
\hline \multirow[t]{5}{*}{$\begin{array}{l}\text { Policies } \\
\text { affecting trade } \\
\text { in goods and } \\
\text { services }\end{array}$} & \multirow[t]{3}{*}{$\begin{array}{l}\text { Trade in } \\
\text { goods }\end{array}$} & Import regulations & $\begin{array}{l}\text { Import regimes, customs code, ordinary customs duty, other } \\
\text { duties and charges, TRQ, tariff exemptions, application of } \\
\text { internal taxes on imports, prohibitions, quotas, restrictive } \\
\text { licenses, import licensing procedures, customs valuation, } \\
\text { rules of origin, other customs formalities, pre-shipment } \\
\text { inspection, contingency measures (e.g. anti-dumping, } \\
\text { countervailing or and safeguard measures) }\end{array}$ \\
\hline & & Export regulations & $\begin{array}{l}\text { Tariffs or taxes on exports, export restrictions, export } \\
\text { subsidies, export processing zones }\end{array}$ \\
\hline & & $\begin{array}{l}\text { Internal policies } \\
\text { affecting trade in } \\
\text { goods }\end{array}$ & $\begin{array}{l}\text { Taxes and charges levied on imports, industrial policies } \\
\text { including subsidies, technical barriers to trade (TBT) and } \\
\text { sanitary and phytosanitary measures (SPS), trade-linked } \\
\text { investment measures (TRIMs), state trading entities, } \\
\text { free zones and special economic areas, government } \\
\text { procurement, transit, agricultural policies, trade in civil } \\
\text { aircraft, textiles } \\
\text { Trading rights, (advertising and trade in alcohol and } \\
\text { tobacco) }\end{array}$ \\
\hline & \multicolumn{2}{|c|}{ Trade in services } & $\begin{array}{l}\text { Horizontal commitments (in Modes 1, 2, 3, 4), MFN } \\
\text { exemption, full or partial commitments in the following } \\
\text { services - business, communication, construction, } \\
\text { distribution, educational, environmental, financial, health, } \\
\text { tourism and travel-related, transport. }\end{array}$ \\
\hline & \multicolumn{2}{|c|}{$\begin{array}{l}\text { Trade-Related Intellectual } \\
\text { Property Rights (TRIPS) }\end{array}$} & Obligations stipulated in the TRIPS Agreement \\
\hline \multicolumn{3}{|c|}{ Other related policies } & $\begin{array}{l}\text { Non-discrimination, foreign exchange and payments, } \\
\text { balance-of-payment measures, investment regime, State } \\
\text { ownership and privatization, pricing policies }\end{array}$ \\
\hline \multicolumn{3}{|c|}{ Policies affecting institutions } & $\begin{array}{l}\text { Structure and powers of government; powers, executive, } \\
\text { legislative and judiciary administration of policies on } \\
\text { WTO-related issues; authority of sub-central governments; } \\
\text { uniform administration of trade regime; judicial review } \\
\text { (including the right of appeal) }\end{array}$ \\
\hline
\end{tabular}

Source: Technical Note on the Accession Process, WT/ACC/10/Rev.3, 2005, and http://www.wto.org/english/ thewto_e/acc_e/acc_e.htm .

policies to initiate domestic economic policy reform measures.

In other words, table 1 shows that the WTO accession process does not limit itself to trade policy measures and/or external sector liberalization. The accession package deal is indeed intended to bring about substantial reform of domestic economy policy that may help to reduce constraints, on both the economic and institutional fronts. Given this perspective, we argue that a single measure to identify the impact of WTO accession on a country may not be fully appropriate, and one ought to look for a composite measure of economic policies and institutions.

More specifically, by looking at the above table 1 , we observe that the institutional dimensions consist of the following aspects: the structure and powers of Government and of the Executive, the Legislative and the Judiciary; 
the administration of policies on WTO-related issues; the authority of sub-central governments; the uniform administration of the trade regime; judicial review; publication of information on trade and trade laws; and submission of WTO notifications. The WTO accession-related rules can clearly help stimulate tangible changes in institutions, in the case of economic policy measures, which are directly related to import and export regulations and policies, and TRIPs issues, etc. Hence we argue in favour of using a composite measure of economic policy and institutions in this paper.

Therefore, the purpose here is to explain and provide empirical evidence for the fact that due to WTO membership requirements, there have been substantial changes in economic policy and institution-building after controlling for GATT/WTO developing country members.

Moreover, WTO accession requires countries to prepare a policy commitment in several key areas as against the particular institution that must be created, strengthened or updated in the acceding country, thereby giving guidance on the full panoply of tradeand development-related institutions that will be influenced by accession to WTO. Table 2 shows how the accession process can help bring about changes in national economic policies and traderelated institution building. Once a country begins its negotiation process with the existing WTO members, it has to go through a long-drawn process which is expected to eventually bring a substantial change in policy areas and in creating more efficient trade-related institutions.

Table 2 presents an example of what a developing country, acceding and/or implementing multilateral trade rules, will involve in terms of institutional changes. That, in turn, can suggests the areas where external support may be expected from, e.g. the Aid for Trade (AfT) initiative.

Although developing countries still receive some form of special and differential treatment (SDT), this is mainly on the basis of temporary exemptions from some provisions of the new agreements and longer implementation periods (that have mostly expired). As a result of stricter application of the reciprocity principle, developing countries are now in general expected to have national trade regimes as open as those of the developed countries. Thus, the new underlying logic in the trading system's approach to trade and development is equality of trade opportunity for developed and developing countries alike (despite inequality of capacities), rather than the provision of effective flexibilities of rules and disciplines and meaningful responses to the specific structural problems of developing countries. New members that have acceded to WTO in 1995-2007 are in fact subject to this logic in an even more pronounced manner.

It may be noted that in the context of making changes in national policy and institutional framework, negotiations on the terms of accession take place on two tracks - a multilateral and a bilateral track. First, within a multilateral Working Party on each accession case, WTO members investigate whether any economic policy measure of a country seeking accession is inconsistent with the WTO rules. When an inconsistency is found, the country is expected to demonstrate how it plans to reform the concerned policy area. ${ }^{23}$ Second, in parallel to the multilateral track, an acceding country is requested to negotiate bilaterally with interested WTO members over how many "concessions" it makes in terms of opening its market in goods and services to exports from WTO members. Concessions cover binding MFN tariffs at "commercially viable levels"; making rules transparent across all domestic services sectors ("horizontal commitments"); and totally or partially opening up specific service sectors such as telecommunications, professional and financial services. Upon the completion of multilateral and bilateral negotiations, the agreed terms of accession are specified in the Working Party Report, which includes legislative action plans (LAPs) mapping out intended institutional changes and the country' Schedules

\footnotetext{
23 Note also that quite a number of newly acceded countries made commitments that go beyond the coverage of the existing WTO rules, for example, with regard to privatization of State-owned enterprises, pricing policies, export duties and taxes, protection of intellectual property rights, trade-related investment measures and overall transparency requirements. Such commitments are referred to as "WTO-plus", as they exceed the level of obligations that applies to existing WTO members.
} 
Table 2. Illustrative interplay between international institutions (multilateral trade rules) and national trade-related institutions

\begin{tabular}{|c|c|c|}
\hline WTO institutional area & National policy areas affected & Change in national institutions required \\
\hline Import tariffs & $\begin{array}{l}\text { Government revenues, } \\
\text { industrial and customs policy }\end{array}$ & $\begin{array}{l}\text { Bound levels of tariffs for both industrial and } \\
\text { agricultural goods }\end{array}$ \\
\hline $\begin{array}{l}\text { Fees and charges for imports } \\
\text { and exports }\end{array}$ & Government revenues & $\begin{array}{l}\text { Fees and charges should be limited to the } \\
\text { approximate cost of services rendered }\end{array}$ \\
\hline Internal taxes & Government revenues & $\begin{array}{l}\text { Internal taxes should be equal to similar } \\
\text { domestic and imported products }\end{array}$ \\
\hline $\begin{array}{l}\text { Quantitative import and } \\
\text { export restrictions on goods }\end{array}$ & $\begin{array}{l}\text { Agricultural and industrial } \\
\text { policies }\end{array}$ & Quantitative restrictions are prohibited \\
\hline Import licensing & $\begin{array}{l}\text { Agricultural and industrial } \\
\text { policies }\end{array}$ & $\begin{array}{l}\text { Import licensing should be transparent and } \\
\text { subject to simple and clear procedures }\end{array}$ \\
\hline Customs valuation & Customs policy & $\begin{array}{l}\text { Application of defined valuations methods; } \\
\text { prohibition of minimal values for customs } \\
\text { purposes }\end{array}$ \\
\hline $\begin{array}{l}\text { Anti-dumping, } \\
\text { countervailing duties and } \\
\text { safeguard regimes }\end{array}$ & $\begin{array}{l}\text { Agricultural and industrial } \\
\text { policies }\end{array}$ & $\begin{array}{l}\text { Adoption of special laws and regulations, } \\
\text { including establishment of special responsible } \\
\text { bodies }\end{array}$ \\
\hline Export subsidies & $\begin{array}{l}\text { Agricultural and industrial } \\
\text { policies }\end{array}$ & $\begin{array}{l}\text { Export subsidies on industrial products are } \\
\text { prohibited and bound at zero for agricultural } \\
\text { products }\end{array}$ \\
\hline Internal subsidies & $\begin{array}{l}\text { Agricultural and industrial } \\
\text { policies }\end{array}$ & $\begin{array}{l}\text { Industrial subsidies are subject to specific } \\
\text { rules; } \\
\text { Agricultural subsidies are bound at specific or } \\
\text { de minimis levels }\end{array}$ \\
\hline $\begin{array}{l}\text { Technical barriers to trade } \\
\text { (TBT) }\end{array}$ & $\begin{array}{l}\text { Agricultural and industrial } \\
\text { policies }\end{array}$ & $\begin{array}{l}\text { Special laws and regulations to cover technical } \\
\text { regulations, standards and conformity } \\
\text { assessment systems, including transparency } \\
\text { and establishment of enquiry points }\end{array}$ \\
\hline $\begin{array}{l}\text { Sanitary and phytosanitary } \\
\text { measures (SPS) }\end{array}$ & Agricultural policy & $\begin{array}{l}\text { Special laws and regulations to cover risk } \\
\text { assessment and other required multilateral } \\
\text { rules, including transparency and } \\
\text { establishment of inquiry points }\end{array}$ \\
\hline $\begin{array}{l}\text { Trade-related investment } \\
\text { measures (TRIMS) }\end{array}$ & $\begin{array}{l}\text { Agricultural, industrial and } \\
\text { investment policies }\end{array}$ & TRIMS are prohibited \\
\hline Services sectors & Economic and social policies & $\begin{array}{l}\text { Laws and regulations on access of foreign } \\
\text { services to national market }\end{array}$ \\
\hline $\begin{array}{l}\text { Trade-related intellectual } \\
\text { property rights (TRIPS) }\end{array}$ & $\begin{array}{l}\text { Economic and social policies, } \\
\text { and national law systems }\end{array}$ & $\begin{array}{l}\text { Laws and regulations to conform to the TRIPS } \\
\text { Agreement and its enforcement on copyright } \\
\text { and related rights, trademarks, geographical } \\
\text { indications, industrial designs, patents, plant } \\
\text { variety protection, layout designs for integrated } \\
\text { circuits, undisclosed information, etc. }\end{array}$ \\
\hline
\end{tabular}

Note: Some of the categories such as TBT, SPS, anti-dumping and subsidies under the "WTO Institutional

Area" are categorized in the UNCTAD classification as non-tariff measures (NTMs). 
of Concessions in Goods and Services. ${ }^{24}$ These documents are legally binding under the Protocol of Accession, i.e. they cannot be altered unilaterally by the acceding country without a priori consultations and negotiations with other WTO members.

Some general cross-country studies have covered the policy and institutional impact assessment component of accession to WTO. ${ }^{25}$ In a study of theimpact of WTOaccession on economies in transition, Drabek and Bacchetta (2004) found that WTO membership brought significant improvement in governance and economic policies. In the discussion of several accession cases, Kennett et al (2005) highlighted the legal obligations and their implications. Ferrantino (2006) explored the effects of WTO accessions on governance, concluding that the World Bank's "Governance Matters" indicators showed no apparent relationship between accession to WTO and improvement in the quality of governance. Tang and Wei (2006) explored the consequences of WTO accessions on income and investment, finding evidence that WTO accession accelerated income and investment provided countries had accepted rigorous accession commitments. These studies have not discussed the full range of links between the accession to WTO and changes in domestic policies and institutions; unsurprisingly in view of differences in their country coverage, their conclusions as to the strength of the effects of WTO accession vary. ${ }^{26}$

\footnotetext{
24 Legislative Action Plans have now become a requirement in all accessions, although they were not requested in the earlier cases.

25 See Basu (2008) for further discussion on role of institutions.

26 See also Oxfam International (2003) on Cambodia's accession and its impact.
}

\section{MODEL-BASED ANALYSIS OF WTO ACCESSION AND THE BUILDING OF TRADE-RELATED INSTITUTIONS}

This section provides results from qualitative and econometric models. Initially, we set out briefly the descriptive statistics of basic economic information, EFI and ICRG measures to indicate the economic policy changes and institutional quality for acceding countries. We present results for 21 members that have completed the accession procedures, as Viet Nam and Tonga are not taken into account for the empirical analysis.

\subsection{WTO accession: A qualitative analysis of economic conditions}

The WTO members have undergone many policy changes during the process of accession. We document here some evidence of changes over the period for 23 newly acceded members, which provided them a gateway to enjoy the benefits through a multilateral trading system. These members are now eligible for most-favoured-nation (MFN) treatment on all their economic transactions from other member countries. The statistics show that the population size of new members is relatively small, except for China (Appendix table A1).

The new members show considerable divergence in economic size, levels of development and degree of participation in world trade (see Appendix tables A4, A5, and A6):

- Though the majority of new members are relatively small in terms of population except for China, GDP per capita (in US\$) varies across countries, ranging from a minimum of US\$270.7 for Nepal for 2005 to a maximum of US $\$ 15,291.5$ for Chinese Taipei (referred to in the United Nations as Taiwan Province of China) (see table A4).

- The level of participation in international trade for each member is depicted by its share of global merchandise trade. Only China experienced a significant rise of its 
share from $2.88 \%$ in 1995 to $7.28 \%$ in 2005 (see table A5).

- They also vary in terms of their trade-toGDP ratio. ${ }^{27}$ The trade/GDP ratio for Nepal, for example, is less than 50 per cent, while that of Estonia is almost 165 per cent.

- The new members have reduced their applied MFN tariff rates since the date of their first Working Party meeting (see table A6). ${ }^{28}$ In the base year (i.e. 1995), there were thirteen members with average tariff rates exceeding 10 per cent, but in the latest year (2005) for which data were available the number had declined to six members. The maximum average tariff rate in the base year was 35.5 per cent (China), but only 16.8 per cent (Viet Nam) in the latest year.

The descriptive statistics of above indicators for two separate years are also presented (Appendix table A7). They show that average per capita GDP has a significant amount of dispersion among countries, trade/GDP ratio has increased and MFN tariff rates have declined significantly over the period. The share of merchandise exports (\% of world) increased from 0.32 per cent to 0.51 per cent over the past decade, as did imports. Therefore, it provides some initial association indicating the fact that countries with falling tariff rates are engaging in more trade.

Another crucial element of the accession process is the statistics related to the number of "systemic" (or institutional) commitments made by these members in the Working Party Report (Appendix table A8). The width of the terms of accession refers to the range of issues in which acceding countries are required to reform their economic policies and institutions. On average, new members made commitments in 23 policy areas. By taking statistics, we find that the mean number of "areas of commitments" is 23 (excluding China and Chinese Taipei, referred to in the United Nations as Taiwan Province of China,

\footnotetext{
27 See Chapter 1 of this publication. See also Sachs and Warner (1995) and Wacziarg and Welch (2003) for a discussion on trade openness measures.

28 We perform paired mean difference test of two periods across 22 new members. The result is statistically significant at the $1 \%$ level, indicating there has been a significant fall in latest year compared to base tariff rates.
}

is 22). Under each policy area, however, some acceding countries have made much "deeper" commitments than others. The depth of the terms of accession is assessed by the indicating number of commitment paragraphs in the Working Party Report, since these paragraphs refer to the types and the degree of policy and institutional reforms that acceding countries had to undertake. While the average number of "paragraphs of commitments" is 34, Mongolia had the minimum number of paragraphs of commitments (17) while China had the maximum number (82). Another interesting fact is the number of working party members present and negotiated during the accession process. Nepal and Georgia had to hold three meetings each during their accession process, whereas China had to undertake 41 meetings with working party members. The number of working party members is another indication of how existing member countries are interested in particular accession negotiations. A quick look at the table shows that the mean number of members is 28 (excluding China and Chinese Taipei, referred to in the United Nations as Taiwan Province of China, is 24). China had 62 working party members, while Cambodia and Kyrgyz Republic had 15 working party members. Some of these measures provide crucial clues for further exploration of accession impact on domestic economic policies and resulting institutional changes.

\subsection{WTO accession: A qualitative analysis of policy and institutions}

The key question is to trace the changes of newly acceded members during this period on domestic economic policy and institutions. First, we discuss the EFI measure, and then ICRGI. We analyse three groups of WTO members for both the samples in enlarged version by dividing members into the following groups: developing country GATT members only, WTO members and WTO members-Article XXVI:5(c).

We present the results for the EFI sample (see Appendix table A9 for the description of each EFI component and table A10 for the descriptive statistics). This sample consists of a total of 98 countries. The developing country GATT members have an EFI value of 1.73 , as 
compared with 1.85 for the newly acceded WTO members. Moreover, WTO members-Article XXVI:5(c) registered an average value of 1.71 . The figure clearly shows that the value is highest for the newly acceded members, and the maximum value (3.32 for Estonia) in the sample is from this group. Similarly, we present the results from the ICRG sample (see Appendix table A11 for the description of each of ICRG components and table A12 for the descriptive statistics). It consists of 80 developing countries GATT/WTO members. The average of WTO members stands at 4.90, while for the GATT members it is 4.57 and for XXVI:5(c) members it is 3.908 (Appendix table A12 shows). The average of all the developing countries in the sample is 3.92. The above descriptive statistics provide an initial indication that in our sample for both sets of measures, the newly acceded WTO members have performed better that the rest of the groups. This preliminary finding implies that domestic economic policy and institutional changes have been raised substantially over the period for newly acceded members of WTO as compared to the rest.

We also present results of correlation among components of EFI and ICRGI. Secondly, the results on correlation between GDP per capita (log of) with a composite measure, such as EFI and ICRGI, and its constituent components are presented. The correlation matrix of 10 components of EFI is also reported (Appendix table A13). By looking closely at the table, one can observe some interesting relationships among the components. For example, the trade (TD) policy component is significantly correlated with the foreign investment (FI) and banking (BK) component measures of EFI. TD is not statistically significantly correlated with only the monetary policy (MP) component also. Similarly, the property rights (PR) component has the highest correlations with the foreign investment (FI), banking (BK), and wages and prices (WP) component, and the least correlation with the monetary policy (MP) component. Furthermore, the regulation (RE) component of EFI shows maximum correlation with the property rights (PR) component, followed by the foreign investment (FI), banking (BK), and wages and prices (WP) component.
The correlation of foreign investment (FI) with banking (BK) is highest, followed by the wage and prices (WP), property rights (PR) and regulation (RE) component. This indicates that institutional measures are important elements of economic policy change and improvements therein. The domestic economic policy change and institutional measure are all positively related to each other in the EFI sample. Let us now turn to discuss the relationship of the EFI components with GDP per capita (Appendix table A14). The composite measure of 10 components is the Index of Economic Freedom (EFI), which is highly correlated with the GDP per capita (log of) indicator, 0.65 .

By analysing individual components of EFI, we observe that better regulation (RE) is highly correlated with GDP per capita, as are the property rights (PR) component and improvements in the (in)formal market (IM). Monetary policy (MP) and government intervention (GI) components have the least correlations with the GDP per capita component. This shows once again that improved banking (BK) and foreign investment (FI) have statistically significant positive correlation with GDP per capita, as does the trade (TD) component. With all of these domestic policy and institutional measures, it comes out strongly that GDP per capita measure is positively correlated.

The International Country Risk Guide Index (ICRGI) is composed of three components, viz., investment profile (IP), law and order (LO), and bureaucratic quality (BQ). Initially, the correlation among components (Appendix table A15) Investment profile (IP) component of ICRGI is found to be positively correlated (statistically significant) with law and order (LO) and bureaucraticquality(BQ)component. Bureaucratic quality (BQ) has the highest correlation with the law and order (LO) component. Subsequently, the correlations between GDP per capita with three components are shown in the next table (Appendix table A16). The results clearly indicate that bureaucratic quality (BQ) has the highest correlation with GDP per capita, followed by law and order (LO) and investment profile (IP).

Therefore, a high correlation between domestic economic policy components (banking, wages and prices, trade, fiscal burden, foreign 
investment, investment profile) with institutional measures (property rights, regulation, law and order, and bureaucratic quality) should not be interpreted as causation. The preliminary results of inter-relationship among these components with GDP per capita are also encouraging, helping us explore in detail the causal relation through econometric modelling in later sections of this paper.

It may be noted that there is also some indication that the impact of WTO accession on institution-building and on trade performance depend on the level of development, in particular absorption capacity and hence capacity to effectively implement the commitments. It is natural to ask whether and how such divergences among new members are taken into account when negotiating their terms of accession to WTO. This question is the focus of our examination below. The terms of accession agreed by each new member are examined here in terms of their width and depth. ${ }^{29}$

\subsection{WTO accession: A qualitative analysis of terms of accession}

The width of the terms of accession refers to the range of issues in which acceding countries are required to reform their policies and/or institutions. As shown in table 3, width is similar across countries. On average, new members made commitments in twenty-two policy areas which vary little among countries at different income levels. These areas cover the "core" issues of WTO, i.e. those which are closely linked to the WTO/GATT Articles or directly associated with specific WTO agreements such as those on customs valuation, import licensing, anti-dumping, subsidies and countervailing measures, safeguard measures, TRIPs and TRIMs. Such a result suggests that accession negotiations are conducted according to a given framework, whose objective is a systematic check on economic policies that touch upon the core issue covered by the WTO rules. Under each issue, however, some acceding countries have made much "deeper"

Table 3. Depth of commitments in accession agreements

\begin{tabular}{|c|c|c|c|c|c|c|c|c|}
\hline \multicolumn{3}{|c|}{ Low-income group } & \multicolumn{3}{|c|}{ Lower-middle income group } & \multicolumn{3}{|c|}{ Higher-middle income group } \\
\hline & area & para & & area & para & & area & para \\
\hline Kyrgyz Republic (1997) & 21 & 29 & Ecuador (1996) & 17 & 21 & Bulgaria (1996) & 22 & 26 \\
\hline Mongolia (1997) & 20 & 17 & Albania (2000) & 22 & 29 & Panama (1997) & 19 & 24 \\
\hline Moldova (2001) & 24 & 28 & Georgia (2000) & 23 & 29 & Latvia (1999) & 20 & 22 \\
\hline Cambodia (2004) & 24 & 29 & China (2001) & 27 & 82 & Estonia (1999) & 21 & 24 \\
\hline Nepal (2004) & 20 & 25 & Armenia (2003) & 25 & 39 & Croatia (2000) & 22 & 27 \\
\hline \multirow[t]{2}{*}{ Viet Nam } & 30 & 70 & Tonga & 29 & 32 & Jordan (2000) & 23 & 29 \\
\hline & & & & & & Oman (2000) & 24 & 26 \\
\hline \multirow[t]{7}{*}{ Average } & 23.1 & 33.0 & Average & 23.8 & 38.6 & Lithuania (2001) & 22 & 28 \\
\hline & & & (excluding & 23.2 & 30.0 & Chinese Taipei (2002)* & 23 & 63 \\
\hline & & & China) & & & Macedonia, FYR (2003) & 19 & 24 \\
\hline & & & & & & Saudi Arabia (2005) & 26 & 59 \\
\hline & & & & & & Average & 21.9 & 32.0 \\
\hline & & & & & & (excluding Chinese & 24.8 & 25.6 \\
\hline & & & & & & $\begin{array}{l}\text { Taipei* and Saudi } \\
\text { Arabia) }\end{array}$ & & \\
\hline
\end{tabular}

Note: World Bank definition of the Income group: Economies are divided according to 2005 GNI per capita, calculated using the World Bank Atlas method. The groups are: low income, $\$ 875$ or less; lower middle income, $\$ 876$ - $\$ 3,465$; upper middle income, $\$ 3,466$ - $\$ 10,725$; and high income, $\$ 10,726$ or more. Area refers to the number of subjects, and para denotes the number of commitment paragraphs in the Working Party Report.

* Chinese Taipei referred to in the United Nations as Taiwan Province of China.

\footnotetext{
29 The concept of the width and the height was first used by VanGrasstek (2001), though the definition used here is not exactly the same.
} 
commitments than others. The depth of the terms of accession is assessed here by the number of commitment paragraphs in the Working Party Report, since these paragraphs refer to the types and the degree of reforms that new members are called to undertake. As shown in Table 3, the average number of commitment paragraphs (40) is the highest for the lower-middle income group, followed by the higher-middle income group (32) and the lower-income group (33). These averages, however, are greatly influenced by four outliers, China, Viet Nam, Saudi Arabia and Chinese Taipei (referred to in the United Nations as Taiwan Province of China). When these new members are excluded, the depth of commitments does not differ much among countries and income groups, the reduction in depth being due to the exclusion of China, a particularly large country, from the lower-middle income group.

Figure 1. Linking the terms of accession to (1) GDP per capita and (2) a measure of policy and institutional quality
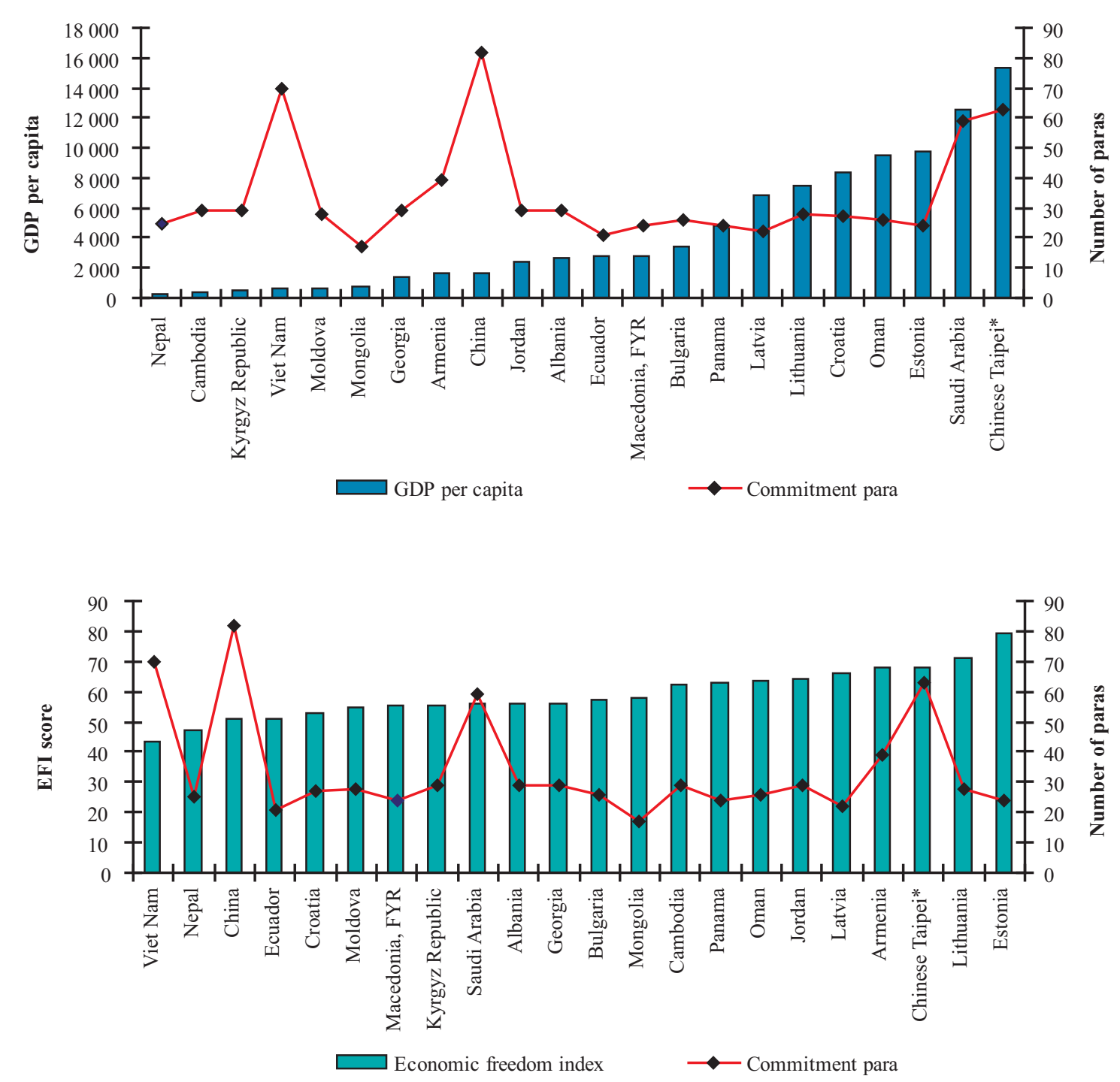

Notes: Commitment para: number of commitment paragraphs in Working Party Report.

Real GDP per capita at constant \$US, EFI: Index of Economic Freedom (a measure of domestic economic policy and institutional quality).

* Chinese Taipei referred to in the United Nations as Taiwan Province of China.

Source: EFI from the Heritage Foundation, GDP per capita from UNCTAD intranet, and Commitment para from the WTO documents. 


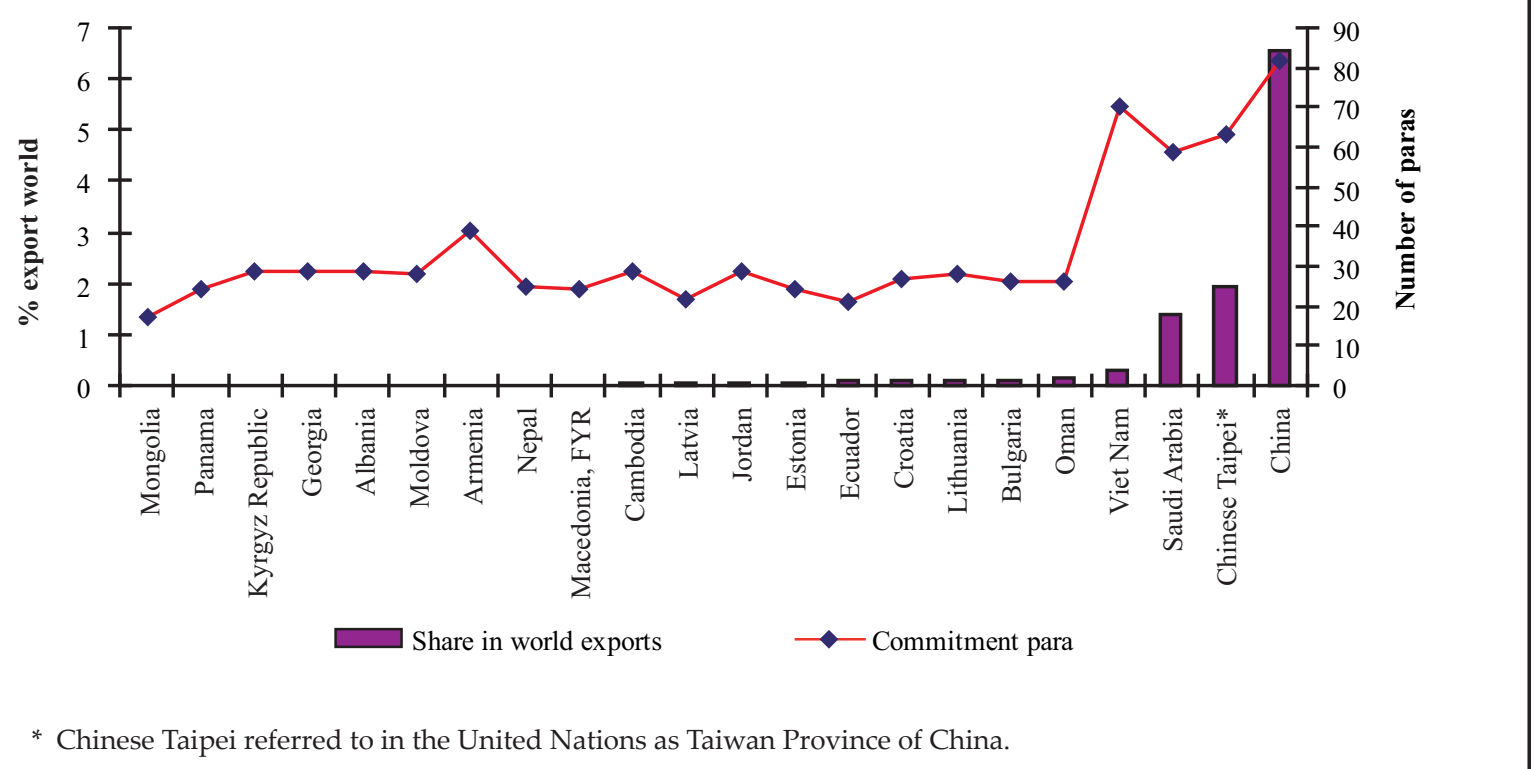

So what determines the divergence in the depth of the terms of accession? Figure 1 shows that depth is not related to either income level or institutional quality as measured by the EFI. The commitments of Cambodia, which is a LDC, were covered by the same number of paragraphs as those of Jordan, a country with a GDP per capita about five times higher; while the commitments of Nepal, another LDC, were covered by one paragraph more than Estonia and Panama, countries almost twenty times richer.

It might be expected that a country with a low level of institutional quality/financial resources should not be required to make a greater number of commitments than others with a better level. But this does not seem to hold. In the lower half of Figure 1, the newly acceded countries are ordered from left to right according to their associated EFI values. There is no apparent relationship between EFI and depth of terms of accession.

However, the depth of terms of accession appears to be related to a member's participation in world trade (see Figure 2). The "outlier" members - China, Chinese Taipei (referred to in the United Nations as Taiwan Province of China) and Saudi Arabia - together account for some 11 per cent of the merchandise export of world trade, while the share of all the remaining members only accounts for 1.1 per cent. The average number of commitment paragraphs for the "outlier" members is 68 , compared to 28.7 for the remaining members. New members with greater participation in world trade and market impact were asked to make greater concessions than other small players. This readily implies that width and depth of commitments vary according to specific commercial interest, size of markets and political economy.

The above examination suggests that the terms of accession resemble a "set menu" in terms of width, i.e. acceding countries face a fixed set of areas for policy and institutional reform regardless of their differing levels of economic development or institutional quality. Moreover, whenever the commercial or political interests of WTO members are at stake in relation to certain acceding countries, the former show greater interest in their trade regimes and institutions and insist on substantially more commitments than in the "set menu".

Indeed, it has been observed that major WTO members use accession negotiations to improve their export opportunities and to block "unfair access" of new members to their home markets. ${ }^{30}$ This may reflect the fact that acceding

\footnotetext{
30 A notable example was the terms of accession for China, which assure a certain share for the exports of major WTO members in its market via tariff rate quotas and which include clauses allowing WTO members to impose safeguard and anti-dumping measures on the basis of special rules and procedures if Chinese exports of certain goods threaten a WTO member's import market. These special provisions are set to expire only after transitional periods of 12 to 15 years.
} 
countries still include "non-market economies", which are deemed to require special approach and disciplines before they make the transition to a "full market economy" and are therefore requested to make much deeper commitments than other acceding countries. WTO members also take advantage of accession negotiations to influence negotiations with countries "in waiting", using the terms of accession to establish precedents for subsequent cases. As a result, terms of accession have tended to become deeper over time.

The above discussion generates some key issues regarding the terms of accession and their impact on acceding countries. For acceding countries at a higher level of development, accession commitments can well induce institution-building and expedite the process of integration into the multilateral trading system (MTS). But the accession process fails to recognize the "readiness quotient" of a country in terms of its institutions and development level. If "readiness" is less, more time should be required for the implementation process, particularly in terms of resource-intensive commitments. Ideally, "demands" on width and depth of concessions should be calibrated according to institutional preparedness and the necessary resources provided in the case of poor countries.

The present reality is that no thought seems to be given to the linkage of readiness and institutional capacity. Accessions are used to extract maximum concessions from acceding countries without any reflection as to the sustainability of such demands, in terms of levels of development, and the institutional preparedness of the countries in question.

\subsection{WTO accession: A quantitative analysis}

In this section, we set up and examine through econometric specification the hypothesis that accession has a positive and significant impact on economic policies and institutions (DEI, for domestic economic policy). In other words, if accession to the WTO influences policies and institutions in the acceding country, what is the extent of this influence?
In order to capture the changes in DEI, two measures are used for the dependent variable - one for the baseline estimation and another for checking the model's robustness. The measure for the baseline estimation is the Index of Economic Freedom (EFI) estimated by the Heritage Foundation. The EFI is a composite measure constructed from ten indicators trade, fiscal burden, monetary policy, foreign investment, banking, wages and prices, property rights, regulation, and international market. The data are estimated for 101 developing countries during the period 1995-2004. It should be noted that the EFI has not been constructed to take into account the accession impacts on domestic economic and institutional quality. However, the constituents of the index can capture some aspects of accession commitments.

The second measure (for robustness analysis) of the dependent variable is obtained from PRS group data on the International Country Risk Guide (ICRG) that helps identify the riskmeasure of business investment by companies. ${ }^{31}$ PRS Group has provided 'perception'-based data and information on a monthly basis since 1984 on a number of risk components, helping to identify policy and institution-related developments for more than 130 countries. We included three components from their dataset, which are related to countries' economic policies and institutions, such as Investment Profile (IP), Law and Order (LO) and Bureaucracy Quality (BQ). The data are used since 1995 to 2004 for 81 developing countries, including GATT/WTO members. Therefore, in this paper, we use two measures of DEI (i.e. EFI or ICRG) to identify the impact of WTO accession negotiation during the treatment period.

The key independent variable in this paper is the WTO accession dummy variable. This is computed from the information on member countries of WTO documents, which can be downloaded directly from the WTO website. ${ }^{32}$ The control variable in all of the specifications is lagged GDP per capita (log of), which is obtained

\footnotetext{
31 On the PRS Group website, they claim that "You can trust the PRS Group to bring you the accurate and timely information you need to make the decisions that are crucial to your business" (http://www.prsgroup.com/)

32 See http://www.wto.org/English/thewto_e/acc_e/acc_e. htm for relevant country-wise accession documents.
} 
from the World Bank's World Development Indicators (2006).

The test uses the tool of differencein-difference (DD) analysis, which relies on dummy variables to segment the observations for countries and years in such a way as to produce estimates of the effects of WTO accession on DEI. ${ }^{33}$ The hypothesis is accepted if countries that went through the accession process show higher levels of improvements in DEI than other developingcountry members of the GATT/WTO. ${ }^{34}$ Twentyone newly acceded countries are defined as the 'treatment group' and other developing countries which are GATT/WTO members as the 'control group' (see Appendix table A17 for the list of countries in the sample for the empirical study). ${ }^{35}$

Let us define the following notations as follows below:

$D E I_{i t}$ is the measure (EFI or ICRG) of domestic economic policy and institutional quality of country $i$ at time period $t$.

$W_{T O d} \in\{0,1\}=$ Dummy variable of whether a country $i$ is member of WTO $(=1)$ or not $(=0)$ at time point $t$ in the sample.

$\triangle D E I_{i t+t^{*}}{ }^{1}=$ Measures (EFI or ICRG) the change in the domestic economic policy and institutions over the treatment period for the treatment group, the newly acceded WTO members.

$\Delta D E I_{i t+t^{*}}{ }^{0}=$ Measures (EFI or ICRG) the change in the domestic economic policy and institutions over the treatment period for the control group.

Therefore, the causal effect of WTO accession negotiation for country $i$ at time point $t$ and $t+t^{*}$ is compared for the outcome of the change in the domestic economic policy and institutions (EFI or ICRG) over the treatment period for the treatment group in comparison to the control group.

\footnotetext{
33 See Meyer (1995), Slaughter (2001) and Bertrand et al (2004) for an in-depth discussion on difference-in-difference analysis.

34 Information on Viet Nam and Tonga are not included in the analysis because of their recent entry to the WTO. We do not have sufficient information to test the impact on their domestic economic policies and institution-building.

35 The selection of sample country depends on the availability of comparable data across variables for all model specifications.
}

Let us now write the average treatments effects (ATE) on the treated in the following form:

$A T E=E\left\{\Delta D E I^{1}{ }_{t+t^{*}} \backslash W T O d_{i t}=1\right\}-E\left\{\Delta D E I_{{ }_{t+t^{*}}}^{0} \backslash W T O d_{i t}=0\right\} \ldots . . .(1)$

In equation (1), $E\left\{\Delta D E I^{1}{ }_{t+t^{*}} \backslash W T O d_{i t}=1\right\}$ measures (EFI or ICRG) the change in the domestic economic policy and institutions in a country $i$ of newly acceded WTO members, while $E\left\{\Delta D E I^{0}{ }_{t+t^{*}}\right\}$ $\left.W T O d_{i t}=0\right\}$ measures the change in the same in a country $i$ for the control group in the respective samples.

By following equation (1), to explore Hypothesis, the difference-in-difference analysis is employed here by estimating the following equation:

$D E I^{T G(=1)}=\alpha_{i}+\beta_{0} W_{T O} d_{i t}+\beta_{1} W_{T O d} d_{i t+t^{*}}+\delta_{0} W \operatorname{TOd}_{i t}^{T G(=1)}+$ $\delta_{1} W_{T O} d_{i t+t^{*}}^{T G(=1)}+\phi X_{i t-1}+\lambda_{t}+\varepsilon^{T G(=1)}$

where $D E I^{T G(=1)}$ it is the measure (EFI or ICRG) for country i belonging to the treatment group of twenty-one recently acceded countries. $\alpha_{i}$ captures fixed effects of country $i$.

$W T O d_{i t}$ is a dummy variable for country $\mathrm{i}$ which is equal to 1 if a country is a member of the WTO at time $\mathrm{t}$ and to 0 if it is not. $\beta_{0}$ thus captures the effect of WTO accession in the year after accession and $\beta_{1}$ the effect of WTO accession in subsequent years for the whole sample of countries in both treatment and control groups.

$W_{T O d^{T G=1}}$ is a dummy variable for country $i$ in the treatment group (the newly acceded countries) which is equal to 1 in the year of accession and 0 otherwise. WTOd $d^{T G=1}{ }_{i t t^{*}}$ is a dummy variable for the same country i which is equal to 0 in years prior to WTO accession and to 1 in the year of WTO accession and subsequent years. $\delta_{0}$ thus captures the additional effect of WTO accession in the year of accession and $\delta_{1}$ the additional effect of WTO accession in subsequent years for the treatment group in comparison to the control group.

$X_{i t-1}$ is the log of lagged GDP per capita which acts as a proxy to capture all other countryspecific variations. $\lambda_{t}$ represents the time-specific effects in the model specification, and $\varepsilon$ is an error term which is assumed to have zero mean and constant variance and not to be autocorrelated. 
However, if we only consider newly acceded WTO members in the sample, then equation (2) boils down to the following:

$D E I_{i t}=\alpha_{\mathrm{i}}+\delta_{0} \mathrm{WTOd}_{i t}+\delta_{1} \mathrm{WTOd}_{i t+t^{*}}+\phi X_{i t-1}+\lambda_{t}+\varepsilon_{i t} \ldots \ldots . . .(3)$

where $D E I_{i t}$ is the measure (EFI or ICRG) of domestic economic policy and institutional quality of country $i$ at time period $t, \delta_{0}$ captures the contemporaneous change in the outcome variable with WTO accession, while $\delta_{1}$ captures the change in outcome variable with after effects of WTO accession. The results are discussed in section 6 .

If accession to the WTO influences traderelated institutions in the acceding country, what is the extent of this influence? In this section, the impact of WTO accession on an acceding country's domestic economic policies and institutional quality (DIQ) is examined through econometric tests of the hypothesis that accession has a positive and significant impact on traderelated institutions.

\subsection{WTO accession: Empirical findings}

To provide empirical support to testable hypotheses, this section intends to discuss results from difference-in-difference analysis. The results from three estimation procedures: ordinary least squares (OLS), feasible generalized least squares (FGLS) and fixed effects (FE) are presented. These model specifications are run with the Index of Economic Freedom (EFI) as dependent variables. For robustness analysis, we use the International Country Risk Guide (ICRG) index as well. Later on, by dropping China and Saudi Arabia from the sample, another set of set of robustness analysis is carried out. ${ }^{36}$ We drop these two countries from the sample for two very specific reasons: (i) total time from application to membership is among the highest for these countries; and (ii) they had to make a maximum number of commitments during the accession negotiations. Previously, it was argued that the number of commitments was related to changes in economic policies and institutions. These two countries may therefore bias the results downward.

\footnotetext{
36 Saudi Arabia does not matter much as after its accession, there is no data point in the sample.
}

The estimation results of the equation 2 (see Section 3.4) are shown in the tables (Appendix table A18, A19 and A20). Results are obtained by considering all developing countries in the sample as the control group. First, OLS (pooled) results for the EFI as the dependent variable are presented (Appendix table A18). The main independent variable is the WTO accession dummy, and lagged GDP per capita (log of) is the control variable. In the first three columns (Col. 1 to Col. 3), we define WTO accession year as a dummy variable, where accession year is 1 and it remains 1 for the rest of the sample time points, and zero otherwise. The first column shows statistically significant positive coefficients of the WTO accession dummy variable (coefficient is 0.138 and significant at $10 \%$ level). The control variable, lagged GDP per capita (log of), is positive and significant in all the different specifications of the model. In column 2, we included time trend $\left\{\right.$ timetrend $\mathrm{d}_{1995}=1$, timetrend $\mathrm{1}_{1996}=2, \ldots .$. .) to account for the overall trend in the EFI, i.e. to understand if there had been any perceptible secular positive trend in economic policy and institutions for these sets of countries in the sample. The positive and significant coefficient on the time trend indicates that the long-run trend of WTO accession for domestic policy changes and institutions is an upwards one. In the Column 3 regression estimation, we include both year effects and time trend, but in that case the coefficient is no longer significant at the $10 \%$ level. This result can follow from the fact that in the simple pooled OLS, by ignoring the country heterogeneity, the year effects may have actually accounted for changes in EFI.

We now show an analytical exercise of WTO accession impact at the domestic level. We postulate that WTO accession could impact on economic policy and institutions for a country which did not go through the accession process (a control country). If OLS is the causal relationship, then the size of the coefficient on the WTO accession dummy suggests its impact on economic policy and institutions, which is measured by EFI. For example, Madagascar did not go through with the WTO accession process, while Lithuania went through the process. The regression coefficient from column 1 of Appendix table A18 indicates that if Madagascar had gone through 
the WTO accession process like Lithuania, then Madagascar would raise its EFI to 1.77, closing the gap with Lithuania from 0.64 point to 0.54 point on average, which is a substantial improvement. The EFI of Madagascar would then become higher than that of developing countries of GATT/WTO average of $1.73 .^{37}$ This simple exercise shows the substantial improvements that could occur if others had gone through the accession process.

In the remaining columns (Col.4 to Col.6), we attempt to understand the impact of WTO accession on economic policy and institutional measures, by isolating the accession time profile into two indicators in the following to ascertain the impact: the year of accession to WTO, and for the subsequent years (Appendix table A18). The economic policy and institutional measures take time to bring about changes due to the lengthy process, and governments need to pursue them on a longer-term basis. The positive reflections on economic outcome measures are not necessarily supposed to occur only in the first year after the accession; rather, results turn out to be substantially improved during subsequent time periods. We can expect WTO $\left(\mathrm{t} 0+\mathrm{t}^{*}\right)$ to be consistently positive, if not WTO (t0). ${ }^{38}$ It is observed that both WTO (t0) and WTO $\left(\mathrm{t}^{0}+\mathrm{t}^{*}\right)$ are positively significant in all the different model specifications; WTO $\left(\mathrm{t} 0+\mathrm{t}^{*}\right)$ being statistically more significant. ${ }^{39}$ Hence the coefficients of the WTO accession dummy designed to estimate the additional effects on DEI for newly acceded countries over a longer period than simply the year of accession are positive and highly statistically significant, as are the coefficients for the proxy variable, (log of) real GDP per capita. The conclusion as to the significance of the influence of WTO accession over a longer period is therefore valid.

\footnotetext{
37 The average of EFI over the period for Lithuania is 2.27, while Madagascar is 1.63 .

38 WTO $(\mathrm{t} 0)=1$ for the year of accession, 0 for the rest of sample period. WTO $\left(\mathrm{t} 0+\mathrm{t}^{*}\right)=1$ for the years after WTO accession, and continues to be 1 for the rest of sample period.

39 The common intercepts hypothesis is rejected in all the model specification as shown by F-statistics. It is noteworthy that throughout this paper, robust standard errors adjusted for clustering by country are reported.
}

The Generalized Least Squares (GLS) estimator is employed because it is consistent and asymptotically more efficient than OLS (Wooldridge 2003). ${ }^{40}$ The GLS estimators are used to account for heteroskedasticity in the error term $\varepsilon .{ }^{41}$ We use FGLS estimation in the presence of panel specific AR (1) autocorrelation, and heteroskedasticity across panels with no crosssectional correlation. ${ }^{42}$ We present Feasible GLS (FGLS) results (Appendix table A19). The overall model specifications remain similar to that with previous findings (Appendix table A18). So, all coefficients of our interest remain positive and highly significant. However, after considering the panel-specific autocorrelation process, results show that the size of standard errors has been drastically reduced without a change in its sign or level of significance.

We can illustrate the estimation results on the basis of Fixed Effects (FE) estimates, which, of the three regression techniques (OLS, GLS and FE) deployed, is intended to eliminate distortions of the parameters from the largest number of possible sources. The FE estimator captures the unobserved country-specific variation in a fixed effects intercept in the model specification. Also, the fixed effects capture the average crosssectional effect over time to account for shifts over time in the countries' relative position to each other in the sample. The fixed effects results of the equation 2 (Section 3) are presented in the following table (Appendix table A20). The first three columns (Col.1 to Col.3) again show that the WTO accession coefficient is positive and significant in all specifications. The coefficient on time trend is positive and significant, which implies there has been upward movement in EFI, so it captures the overall improvement of these treatment group countries (newly acceding countries) that have shown an overall positive upward trend in their domestic economic policies

\footnotetext{
40 Wooldridge further notes that "at any rate, for large sample sizes, FGLS is an attractive alternative to OLS when there is evidence of heteroskedasticity that inflates the standard errors of the OLS estimates".

41 See Hausman and Kuersteiner (2004) on the comparison between feasible GLS and OLS procedures. They note that "corrected FGLS based tests outperforms tests based on OLS"

42 See Bertrand et al (2004) for further dissuasion on the importance to "correct the standard errors assuming that the error term follows an AR(1) process".
} 
and institutions. Column 3 shows results by including time-specific effects, along with time trend, as in column 6 of the same table. The results still remain highly significant for WTO $\left(\mathrm{t} 0+\mathrm{t}^{*}\right)$ variable for columns 5 to columns 6 , but the WTO (t0) coefficient is insignificant. Therefore, the first three tables strongly support our testable hypothesis.

\subsection{WTO accession: Robustness checks of empirical findings}

We now further check the robustness of our hypotheses by including the International Country Risk Guide Index (ICRGI) as the dependent variable. This index is a simple average of three components, viz., investment profile, law and order, and bureaucratic quality. The result of this analysis is reported (Appendix tables A21, A22 and A23). As expected, the WTO accession coefficient is positive and highly significant for three model specifications (OLS, FGLS, and FE).

To carry out another robustness analysis, we report results excluding China and Saudi Arabia from the sample (Appendix table A24). This also reveals that dropping these countries from sample EFI and ICRGI leads to a substantial increase in the size of coefficients on the WTO dummy variable in the fixed effects estimates (see Appendix table A20 column 1 and Appendix table A23 column 1), showing that without China and Saudi Arabia, the WTO accession process substantially boosted countries' economic policies and institutions when compared to other WTO members that did not go through the accession process. More importantly, however, this indicates that, unsurprisingly, the choice of indicator for the dependent variable, DEI, makes a difference for the value of the estimated parameters. However, the conclusion as to the significance of the influence of WTO accession over a longer period stands.

\section{IMPLICATIONS OF ANALYSIS FOR SPECIAL MEASURES TO HELP ACCEDING LDCs}

If the terms of accession are determined regardless of the level of economic development and the institutional quality of acceding countries, it is reasonable to assume that WTO accession could pose a greater burden for countries with limited administrative and institutional capacity, such as LDCs. In fact, WTO members agreed, in the Decision of the WTO General Council of 10 December 2002, that the accession of LDCs should be conducted under a "fast track" approach. The Decision states that "the General Council decides that (...) negotiations for the accession of LDCs to the WTO, be facilitated and accelerated through simplified and streamlined accession procedures, with a view to concluding these negotiations as quickly as possible", and provides a "guideline" as regards negotiations on market access, WTO rules, the negotiation process and provision of technical assistance. ${ }^{43}$

The guideline set out in the Decision, however, provides no practical measures to facilitate and accelerate accession negotiations involving LDCs. For instance, with regard to market access, WTO members are supposed to "exercise restraint" in seeking concessions on trade in goods and services from acceding LDCs, taking into account "the levels of concessions and commitments undertaken by existing WTO LDC Members". However, the tariff concessions made by two LDCs (Cambodia and Nepal) which acceded to WTO after this Decision had come in force brought their average bound tariffs in agriculture to a level of about one-third of the average tariffs of other WTO LDC Members bound under the Uruguay Round.

With respect to rules, the guideline states that “... transitional periods/transitional arrangements foreseen under specific WTO Agreements (...) shall be granted (to acceding LDCs) taking into account individual development, financial and trade needs". But

43 WTO, "Accession of Least-Developed Countries" Decision by the General Council of 10 December 2002 (WT/ L/508). 
there is no guidance as to how individual needs and the feasibility of reforms in the case of LDCs are to be assessed or as to how subsequent implementation of terms of accession is to be monitored. For example, in the case of the accession of Cambodia ${ }^{44}$, it was informally estimated that the implementation costs of compliance with only four WTO multilateral trade agreements (on TRIPS, Customs Valuation, Technical Barriers to Trade and Sanitary/Phytosanitary Measures) would amount to about US $\$ 120$ million per annum during a five-year period after accession. ${ }^{45}$

Accession to the WTO can present a window of opportunity to acceding countries, particularly to those with institutional capacity gaps and deficit such as LDCs, to build stronger trade-related institutions. ${ }^{46}$ In order to take advantage of this opportunity, LDCs require focused and practical support. However, such support has not been forthcoming on the required scale either for recently acceding LDCs or for the thirty other LDCs, most of which acquired GATT membershipthroughsuccession. Theeffectiveness of LDCs' participation in the international trading system is at best partially monitored by the Trade Policy Review Mechanism, which apparently lacks a special framework adapted to the special circumstances of LDCs. ${ }^{47}$

\footnotetext{
44 UNCTAD provided comprehensive technical assistance to Cambodia during its WTO accession process.

45 For further details, see WTO documents WT/ACC/ KHM/13/Rev.1 (3 March 2003), WT/ACC/KHM/14/Rev.1 (3 March 2003), WT/ACC/KHM/15/Rev.1 (3 March 2003) and WT/ ACC/KHM/16/Rev.1 (3 March 2003).

46 The positive impact on trade-related institution-building for LDCs may be the most significant benefit accruing from WTO accession. Other effects which are relatively more important for non-LDCs - such as improving market access, attracting new foreign direct investment and exercising the right to participate in multilateral rulemaking - may not apply to the same extent to LDCs due to their weaknesses. In the case of market access, for instance, over 80 per cent of LDCs' exports to the main developed-country markets already benefit from tariff-free market access under various preferential trade arrangements outside the WTO framework which apply to WTO members and non-members alike.

47 Among possible vehicles for such a mechanism within existing programmes might be the Integrated Framework (IF) for LDCs. New initiatives such as "Aid for Trade" could also be used for this purpose.
}

In order to build a functioning bridge between WTO-induced policy reform and achievement of developmental goals by acceding LDCs, a national mechanism could be established that would serve as an "adjustment and development audit", taking into account, among other things, potential economic costs associated with compliance with WTO rules. ${ }^{48}$ UNCTAD could assist LDCs in this task.

48 See, for instance, Finger and Nogués (2002) for the estimates of costs for developing countries associated with implementing the WTO agreements such as TRIPs, SPS and TBT. 


\section{CONCLUSIONS}

To conclude, it is worthwhile to reiterate that we intended to examine the effects of WTO accession on the domestic economic policies and institutions of newly acceded members in comparison to other developing members in the sample. We argued that measures going beyond usual trade policy and trade outcome should be used to explore WTO accession benefits for newly acceded countries. The preliminary findings show that given the composite measures of domestic economic and institutions, WTO accession had a positive and significant impact for these newly acceded countries after controlling for developing countries in the sample by using difference-indifference analysis. Hence, the WTO accession mechanism could be seen as a package deal that provides countries with opportunities to make credible commitments, by inducing deeper economic policy changes and making institutions respond effectively and efficiently during the process.
Future research could be directed toward quantifying the specific measures of WTO accession package along with their commitments on goods and services. These measures should help to promote better understanding of WTO accession impact in the above areas. It could also be of interest to determine the potentially differential impact of WTO accession on LDCs, oil-rich countries, and newly acceded EU countries. Furthermore, future analysis could be geared to focusing on not only comparing and testing the policy anchor hypothesis of FTAs, RTAs and external-sector-related programmes of international organizations, but also simultaneously looking at the effects, at the national level, for each of these newly acceded countries so that the country-specific characteristics and requirements are adequately recognized. Mechanisms for transmission of the impacts of the accession process should also be expanded and identified. 


\section{REFERENCES}

Acemoglu D, Johnson S and Robinson J (2001). “The colonial origins of comparative development: An empirical investigation", American Economic Review, 91(5), 1369-1401.

Basu SR (2008). A new way to link development to institutions, policies and geography. Policy Issues in International Trade and Commodities, UNCTAD/ITCD/TAB/38, United Nations: New York and Geneva.

Bertrand M, Duflo E and Mullainathan S (2004). “How Much Should We Trust Differences-in-Differences Estimates?", Quarterly Journal of Economics, 119(1), 249-75.

Detken C, Gaspar V and Noblet G (2004). "The New EU Member States Convergence and Stability", The Third ECB Banking Conference 21-22 October 2004, European Central Bank.

Drabek Z and Bacchetta M (2004). “Tracing the Effects of WTO Accession on Policy-Making in Sovereign States: Preliminary Lessons from the Recent Experience of Transition Countries" World Economy 27-7, 1083-1125.

Ferrantino MJ (2006). "Policy Anchors: Do Free Trade Agreements Serve as Vehicles for Developing Country Policy Reform?" No. 2006-04-A, US International Trade Commission.

Finger JM and Nogués J (2002). “The Unbalanced Uruguay Round Outcome: The New Areas in Future WTO Negotiations", The World Economy, Blackwell Publishing, 25(3), 321-340.

Frankel JA (2001). "Assessing the Efficiency Gains from Further Liberalization", in Porter, R.B. et al (eds). "Efficiency, Equity, and Legitimacy: The Multilateral Trading System at the Millennium", Harvard University, and Brookings Institutions Press.

Heritage Foundation (2006). Index of Economic Freedom. http://www.heritage.org/research/features/ index/

Hausman J and Kuersteiner G (2004). “Difference in Difference Meets Generalized Least Squares: Higher Order Properties of Hypotheses Tests", Economics Department, MIT.

Kennett M, Evenett SJ and Gage J (2005). “Evaluating WTO Accessions: Legal and Economic Perspective”, IDRC-Sponsored Research project.

Meyer B (1995). "Natural and Quasi-Natural Experiments in Economics," Journal of Business and Economic Statistics, 13, 151-62.

North D (1993). "Understanding the Process of Economic Change", Forum 7, Institutional Barriers to Economic Change: Cases Considered. Forum Series on the Role of Institutions in Promoting Economic Growth.

Oxfam International (2003). Cambodia's Accession to the WTO: How the law of the jungle is applied to one of the world's poorest countries.

PRS Group (2006). International Country Risk Guide. http://www.prsgroup.com/

Piermartini R and Teh R (2005). "Demystifying Modelling Methods for Trade Policy", WTO Discussion Papers, No. 10. WTO: Geneva.

Rodrik D, Subramanian A and Trebbi F (2004). "Institutions Rule: The Primacy of Institutions over Geography and Integration in Economic Development", Journal of Economic Growth, 9, 131-165. 
Sachs J D and Warner A (1995). “Economic reform and the process of global integration", Brookings Papers on Economic Activity, 1-118.

Slaughter M (2001). “Trade liberalisation and per capita income convergence: A difference-in-difference analysis", Journal of International Economics, 55, 203-228.

Tang M-K and Wei SJ (2006). “Does WTO Accession Raise Income?” WP/06/, International Monetary Fund, Washington, DC.

UNCTAD TRAINS database http://r0.unctad.org/trains/

UNCTAD (2008). South-South Trade in Asia: the Role of Regional Trade Agreements, UNCTAD-JETRO joint publication, UNCTAD/DITC/TAB/MISC/2008/2, Geneva: United Nations.

UNCTAD (2005). "Adjusting to Trade Reforms" (Chapter 3) in Developing Countries in International Trade 2005: Trade and Development Index, New York and Geneva: United Nations.

UNCTAD (2001). WTO Accessions and Development Policies, UNCTAD/DITC/TNCD/11, New York and Geneva: United Nations.

VanGrasstek C (2001). "Why Demands on Acceding Countries Increase over Time: A Three-Dimensional Analysis of Multilateral Trade Diplomacy" in WTO Accessions and Development Policies (UNCTAD, 2001), pp. 78-95, New York and Geneva: United Nations.

Wacziarg R and Welch K H (2003). "Trade Liberalization and Growth: New Evidence," Economics Department Working Paper, Stanford University.

Wooldridge J (2003). Introductory Econometrics: A Modern Approach, Second edition. Cincinnati, OH, South-Western College Publishing.

World Bank (2006). World Development Indicators, CD-Rom. Washington, DC.

World Trade Organization (WTO) (2005). Technical Note on the Accession Process, WT/ACC/10/Rev.3, and http://www.wto.org/english/thewto_e/acc_e/acc_e.htm. All documents related to WTO accession are downloadable at http://www.wto.org/english/thewto_e/countries_e/china_e.htm 


\section{APPENDIX TABLES}

Table A1. Completed WTO accessions since 1995

\begin{tabular}{|c|c|c|c|c|}
\hline & Application & $\begin{array}{l}\text { 1st Meeting of } \\
\text { Working Party (WP) }\end{array}$ & Membership & $\begin{array}{l}\text { Total Time } \\
\text { (Application to } \\
\text { Membership) }\end{array}$ \\
\hline Ecuador & September 1992 & July 1993 & January 1996 & 3 years 4 months \\
\hline Bulgaria & September 1986 & July 1993 & December 1996 & 10 years 3 months \\
\hline Mongolia & July 1991 & June 1993 & January 1997 & 5 years 6 months \\
\hline Panama & August 1991 & April 1994 & September 1997 & 5 years 1 month \\
\hline Kyrgyz Republic & February 1996 & March 1997 & December 1998 & 2 years 10 months \\
\hline Latvia & November 1993 & March 1995 & February 1999 & 5 years 3 months \\
\hline Estonia & March 1994 & November 1994 & November 1999 & 5 years 8 months \\
\hline Jordan & January 1994 & October 1996 & April 2000 & 6 years 4 months \\
\hline Georgia & July 1996 & March 1998 & June 2000 & 4 years 1 month \\
\hline Albania & November 1992 & April 1996 & September 2000 & 7 years 10 months \\
\hline Oman & April 1996 & April 1997 & November 2000 & 4 years 7 months \\
\hline Croatia & September 1993 & April 1996 & November 2001 & 7 years 2 months \\
\hline Lithuania & January 1994 & November 1995 & May 2001 & 7 years 5 months \\
\hline Moldova & November 1993 & June 1997 & July 2001 & 7 years 4 months \\
\hline China & July 1986 & October 1987 & December 2001 & 15 years 5 months \\
\hline Chinese Taipei* & January 1992 & November 1992 & January 2002 & 10 years \\
\hline Armenia & November 1993 & January 1996 & February 2003 & 9 years 3 months \\
\hline Macedonia FYR & December 1994 & July 2000 & April 2003 & 8 years 3 months \\
\hline Nepal & May 1989 & May 2000 & April 2004 & 14 years 11 months \\
\hline Cambodia & December 1994 & May 2001 & October 2004 & 9 years 10 months \\
\hline Saudi Arabia & June 1993 & May 1996 & December 2005 & 12 years 7 months \\
\hline Viet Nam & January 1995 & July 1998 & January 2007 & 12 years \\
\hline Kingdom of Tonga & June 1995 & April 2001 & July 2007 & 6 years 3 months \\
\hline
\end{tabular}

Source: Technical Note on the Accession Process, WT/ACC/10/Rev.3, 2005, and http://www.wto.org/english/thewto_e/ acc_e/acc_e.htm

* Chinese Taipei referred to in the United Nations as Taiwan Province of China. 
Table A2. Founder members of GATT/WTO

\begin{tabular}{|c|c|c|}
\hline Country, Year of Membership & Country, Year of Membership & Country, Year of Membership \\
\hline Angola 8 April 1994 & Grenada 9 February 1994 & Pakistan 30 July 1948 \\
\hline Antigua and Barbuda 30 March 1987 & Guatemala 10 October 1991 & Papua New Guinea 16 December 1994 \\
\hline Argentina 11 October 1967 & Guinea 8 December 1994 & Paraguay 6 January 1994 \\
\hline Australia 1 January 1948 & Guinea Bissau 17 March 1994 & Peru 7 October 1951 \\
\hline Austria 19 October 1951 & Guyana 5 July 1966 & Philippines 27 December 1979 \\
\hline Bahrain 13 December 1993 & Haiti 1 January 1950 & Poland 18 October 1967 \\
\hline Bangladesh 16 December 1972 & Honduras 10 April 1994 & Portugal 6 May 1962 \\
\hline Barbados 15 February 1967 & Hong Kong 23 April 1986 & Qatar 7 April 1994 \\
\hline Belgium 1 January 1948 & Hungary 9 September 1973 & Romania 14 November 1971 \\
\hline Belize 7 October 1983 & Iceland 21 April 1968 & Rwanda 1 January 1966 \\
\hline Benin 12 September 1963 & India 8 July 1948 & Senegal 27 September 1963 \\
\hline Bolivia 8 September 1990 & Indonesia 24 February 1950 & Sierra Leone 19 May 1961 \\
\hline Botswana 28 August 1987 & Ireland 22 December 1967 & Singapore 20 August 1973 \\
\hline Brazil 30 July 1948 & Israel 5 July 1962 & Slovak Republic 15 April 1993 \\
\hline Brunei Darussalam 9 December 1993 & Italy 30 May 1950 & Slovenia 30 October 1994 \\
\hline Burkina Faso 3 May 1963 & Jamaica 31 December 1963 & Solomon Islands 28 December 1994 \\
\hline Burundi 13 March 1965 & Japan 10 September 1955 & South Africa 13 June 1948 \\
\hline Cameroon 3 May 1963 & Kenya 5 February 1964 & Spain 29 August 1963 \\
\hline Canada 1 January 1948 & Korea, Republic of 14 April 1967 & Sri Lanka 29 July 1948 \\
\hline Central African Republic 3 May 1963 & Kuwait 3 May 1963 & Saint Kitts and Nevis 24 March 1994 \\
\hline Chad 12 July 1963 & Lesotho 8 January 1988 & Saint Lucia 13 April 1993 \\
\hline Chile 16 March 1949 & Liechtenstein 29 March 1994 & St. Vincent and the Grenadines 18 May 1993 \\
\hline Colombia 3 October 1981 & Luxembourg 1 January 1948 & Suriname 22 March 1978 \\
\hline Congo, Republic of 3 May 1963 & Macao 11 January 1991 & Swaziland, Kingdom of 8 February 1993 \\
\hline Costa Rica 24 November 1990 & Madagascar 30 September 1963 & Sweden 30 April 1950 \\
\hline Côte d'Ivoire 31 December 1963 & Malawi 28 August 1964 & Switzerland 1 August 1966 \\
\hline Cuba 1 January 1948 & Malaysia 24 October 1957 & Tanzania (United Rep. of) 9 December 1961 \\
\hline Cyprus 15 July 1963 & Maldives 19 April 1983 & Thailand 20 November 1982 \\
\hline Czech Republic 15 April 1993 & Mali 11 January 1993 & Togo 20 March 1964 \\
\hline Denmark 28 May 1950 & Malta 17 November 1964 & Trinidad and Tobago 23 October 1962 \\
\hline Djibouti 16 December 1994 & Mauritania 30 September 1963 & Tunisia 29 August 1990 \\
\hline Dominica 20 April 1993 & Mauritius 2 September 1970 & Turkey 17 October 1951 \\
\hline Dominican Republic 19 May 1950 & Mexico 24 August 1986 & Uganda 23 October 1962 \\
\hline Egypt 9 May 1970 & Morocco 17 June 1987 & United Arab Emirates 8 March 1994 \\
\hline El Salvador 22 May 1991 & Mozambique 27 July 1992 & United Kingdom 1 January 1948 \\
\hline Fiji 16 November 1993 & Myanmar, Union of 29 July 1948 & United States of America 1 January 1948 \\
\hline Finland 25 May 1950 & Namibia 15 September 1992 & Uruguay 6 December 1953 \\
\hline France 1 January 1948 & Netherlands 1 January 1948 & Venezuela (Bolivarian Rep. of) 31 Aug 1990 \\
\hline Gabon 3 May 1963 & New Zealand 30 July 1948 & Yugoslavia 25 August 1966 \\
\hline The Gambia 22 February 1965 & Nicaragua 28 May 1950 & Zaire 11 September 1971 \\
\hline Germany 1 October 1951 & Niger 31 December 1963 & Zambia 10 February 1982 \\
\hline Ghana 17 October 1957 & Nigeria 18 November 1960 & Zimbabwe 11 July 1948 \\
\hline Greece 1 March 1950 & Norway 10 July 1948 & \\
\hline
\end{tabular}

Source: http://www.wto.org/english/thewto_e/gattmem_e.htm 
Table A3. Ongoing accessions to the WTO (updated 14 February 2008)

\begin{tabular}{|c|c|c|c|c|c|c|}
\hline & Application & $\begin{array}{l}\text { Working } \\
\text { Party } \\
\text { Established }\end{array}$ & Memorandum & $\begin{array}{l}\text { First/Latest* } \\
\text { Working Party } \\
\text { Meeting }\end{array}$ & $\begin{array}{l}\text { Number of } \\
\text { Working } \\
\text { Party } \\
\text { Meetings * }\end{array}$ & $\begin{array}{l}\text { Draft } \\
\text { Working } \\
\text { Party } \\
\text { Report ** }\end{array}$ \\
\hline Afghanistan & Nov 2004 & Dec 2004 & & & & \\
\hline Algeria & Jun 1987 & Jun 1987 & Jul 1996 & Apr 1998/Feb 2005 & 8 & Feb 2005 \\
\hline Andorra & Jul 1999 & Oct 1997 & Mar 1999 & Oct 1999 & 1 & \\
\hline Azerbaijan & Jun 1997 & Jul 1997 & Apr 1999 & Jun 2002/Oct 2004 & 2 & \\
\hline Bahamas & May 2001 & Jul 2001 & & & & \\
\hline Belarus & Sep 1993 & Oct 1993 & Jan 1996 & Jun 1997/Sep 2004 & 6 & Jul 2004 (FS) \\
\hline Bhutan & Sep 1999 & Oct 1999 & Feb 2003 & Nov 2004 & 1 & \\
\hline $\begin{array}{l}\text { Bosnia and } \\
\text { Herzegovina }\end{array}$ & May 1999 & Jul 1999 & Oct 2002 & Nov 2004/Dec 2004 & 2 & \\
\hline Cape Verde & Nov 1999 & Jul 2000 & Jul 2003 & Mar 2004/Dec 2004 & 2 & Oct 2004 (FS) \\
\hline Ethiopia & Jan 2003 & Feb 2003 & & & & \\
\hline Iran & Jul 1996 & May 2005 & & & & \\
\hline Iraq & Sep 2004 & Dec 2004 & & & & \\
\hline Kazakhstan & Jan 1996 & Feb 1996 & Sep 1996 & Mar 1997/Nov 2004 & 7 & Sep 2004 (FS) \\
\hline $\begin{array}{l}\text { Lao People's } \\
\text { Democratic Republic }\end{array}$ & Jul 1997 & Feb 1998 & Mar 2001 & Oct 2004 & 1 & \\
\hline Lebanese Republic & Jan 1999 & Apr 1999 & Jun 2001 & Oct 2002/Jul 2004 & 3 & Jun 2004 (FS) \\
\hline $\begin{array}{c}\text { Libyan Arab } \\
\text { Jamahiriya }\end{array}$ & Jun 2004 & Jul 2004 & & & & \\
\hline Montenegro & Dec 2004 & Feb 2005 & Mar 2005 & & & \\
\hline Russian Federation & Jun 1993 & Jun 1993 & Mar 1994 & Jul 1995/Apr 2005 & 27 & Oct 2004 \\
\hline Samoa & Apr 1998 & Jul 1998 & Feb 2000 & Mar 2002 & 1 & Jun 2003 \\
\hline $\begin{array}{l}\text { Sao Tome and } \\
\text { Principe }\end{array}$ & Jan 2005 & May 2005 & & & & \\
\hline Serbia & Dec 2004 & Feb 2005 & Mar 2005 & & & \\
\hline Seychelles & May 1995 & Jul 1995 & Aug 1996 & Feb 1997 & 1 & June 1997 \\
\hline Sudan & Oct 1994 & Oct 1994 & Jan 1999 & Jul 2003/Mar 2004 & 2 & Sep 2004 (FS) \\
\hline Tajikistan & May 2001 & Jul 2001 & Feb 2003 & Mar 2004 & 1 & Apr 2005 (FS) \\
\hline Ukraine & Nov 1993 & Dec 1993 & Jul 1994 & Feb 1995/Mar 2005 & 14 & Mar 2005 \\
\hline Uzbekistan & Dec 1994 & Dec 1994 & Oct 1998 & Jul 2002/Jun 2004 & 2 & \\
\hline Vanuatu & Jul 1995 & Jul 1995 & Nov 1995 & Jul 1996/Oct 1999 & 2 & $\begin{array}{l}\text { Accession } \\
\text { Package } \\
\text { Oct } 2001\end{array}$ \\
\hline Yemen & Apr 2000 & Jul 2000 & Nov 2002 & Nov 2004 & 1 & \\
\hline
\end{tabular}

Note: $\quad *$ As of the date of this document.

** Most recent Factual Summary (FS), draft Working Party Report or Elements of draft Working Party Report. 
Table A4. Population, GDP per capita and Trade/GDP of 23 newly acceded WTO members

\begin{tabular}{|c|c|c|c|c|}
\hline & \multirow{2}{*}{$\begin{array}{c}\text { Population } \\
\text { (in Million) } \\
2005\end{array}$} & \multirow{2}{*}{$\begin{array}{c}\text { GDP per capita } \\
\text { (current \$US) } \\
2005\end{array}$} & \multicolumn{2}{|c|}{ Trade/GDP ratio } \\
\hline & & & 1995 & 2005 \\
\hline Ecuador & 13 & 2739.9 & 54.0 & 63.0 \\
\hline Bulgaria & 7.8 & 3442.5 & 91.0 & 138.0 \\
\hline Mongolia & 2.5 & 736.3 & 97.2 & 160.0 \\
\hline Panama & 3.2 & 4786.3 & 198.8 & 141.0 \\
\hline Kyrgyz Republic & 5.1 & 473.4 & 71.8 & 97.0 \\
\hline Latvia & 2.3 & 6856.7 & 87.5 & 111.0 \\
\hline Estonia & 1.3 & 9744.6 & 144.5 & 175.0 \\
\hline Jordan & 5.4 & 2376.7 & 124.6 & 145.0 \\
\hline Georgia & 4.5 & 1429.2 & 67.8 & 97.0 \\
\hline Albania & 3.1 & 2677.4 & 47.0 & 68.0 \\
\hline Oman & 2.5 & 9460.1 & 79.6 & 99.7 \\
\hline Croatia & 4.4 & 8417.7 & 88.1 & 103.0 \\
\hline Lithuania & 3.4 & 7465.5 & 111.0 & 124.0 \\
\hline Moldova & 4.2 & 691.0 & 107.3 & 144.0 \\
\hline China & 1296.2 & 1708.6 & 43.9 & 69.0 \\
\hline Chinese Taipei* & 22.6 & 15291.5 & NA & 120.2 \\
\hline Armenia & 3.0 & 1625.4 & 86.1 & 67.0 \\
\hline Macedonia, FYR & 2.0 & 2832.8 & 75.8 & 108.0 \\
\hline Nepal & 26.6 & 270.7 & 59.5 & 49.0 \\
\hline Cambodia & 13.8 & 383.1 & 77.7 & 139.0 \\
\hline Saudi Arabia & 24.0 & 12606.4 & 65.4 & 87.0 \\
\hline Viet Nam & 82.2 & 631.7 & 74.7 & 145.0 \\
\hline Kingdom of Tonga & 0.102 & 2159.0 & 52.0 & 54.0 \\
\hline
\end{tabular}

Note: NA: Not available.

* Chinese Taipei referred to in the United Nations as Taiwan Province of China.

Source: UNCTAD database, WTO 2007 database, and World Bank 2007 database. 
Table A5. Shares of merchandise exports and imports of 23 newly acceded WTO members (\% of the world)

\begin{tabular}{|c|c|c|c|c|}
\hline & \multicolumn{2}{|c|}{ Export Share } & \multicolumn{2}{|c|}{ Import Share } \\
\hline & 1995 & 2005 & 1995 & 2005 \\
\hline Ecuador & 0.083 & 0.096 & 0.079 & 0.096 \\
\hline Bulgaria & 0.104 & 0.112 & 0.108 & 0.169 \\
\hline Mongolia & 0.009 & 0.010 & 0.008 & 0.011 \\
\hline Panama & 0.012 & 0.010 & 0.048 & 0.039 \\
\hline Kyrgyz Republic & 0.008 & 0.006 & 0.010 & 0.010 \\
\hline Latvia & 0.025 & 0.049 & 0.035 & 0.080 \\
\hline Estonia & 0.036 & 0.074 & 0.046 & 0.095 \\
\hline Jordan & 0.034 & 0.041 & 0.071 & 0.098 \\
\hline Georgia & 0.003 & 0.008 & 0.007 & 0.023 \\
\hline Albania & 0.004 & 0.006 & 0.014 & 0.024 \\
\hline Oman & 0.117 & 0.179 & 0.081 & 0.082 \\
\hline Croatia & 0.087 & 0.084 & 0.141 & 0.172 \\
\hline Lithuania & 0.052 & 0.113 & 0.070 & 0.144 \\
\hline Moldova & 0.014 & 0.010 & 0.016 & 0.021 \\
\hline China & 2.877 & 7.280 & 2.526 & 6.131 \\
\hline Chinese Taipei* & 2.157 & 1.890 & 1.983 & 1.696 \\
\hline Armenia & 0.005 & 0.009 & 0.013 & 0.016 \\
\hline Macedonia FYR & 0.023 & 0.020 & 0.033 & 0.030 \\
\hline Nepal & 0.007 & 0.008 & 0.025 & 0.017 \\
\hline Cambodia & 0.017 & 0.028 & 0.023 & 0.036 \\
\hline Saudi Arabia & 0.968 & 1.725 & 0.537 & 0.552 \\
\hline Viet Nam & 0.105 & 0.310 & 0.156 & 0.344 \\
\hline Kingdom of Tonga & 0.000 & 0.000 & 0.001 & 0.001 \\
\hline
\end{tabular}

* Chinese Taipei referred to in the United Nations as Taiwan Province of China.

Source: UNCTAD Handbook of Statistics 2008 (updated January 2008). 
Table A6. MFN Tariff Rates (simple average) of 23 newly acceded WTO members

\begin{tabular}{|c|c|c|c|c|}
\hline & Base year & Latest year & Change & Rank \\
\hline Ecuador & 12.9 & 11.7 & -1.2 & 15 \\
\hline Bulgaria & 12.3 & 10.4 & -1.9 & 13 \\
\hline Mongolia & NA & 4.5 & & \\
\hline Panama & 12.2 & 7.3 & -4.9 & 7 \\
\hline Kyrgyz Republic & 8.5 & 4.8 & -3.7 & 8 \\
\hline Latvia & 3.8 & 5.4 & 1.6 & 19 \\
\hline Estonia & 1.6 & 5.4 & 3.8 & 21 \\
\hline Jordan & 22.1 & 11.5 & -10.6 & 2 \\
\hline Georgia & 10.6 & 7.0 & -3.6 & 9 \\
\hline Albania & 15.9 & 5.7 & -10.2 & 3 \\
\hline Oman & 7.7 & 5.3 & -2.4 & 11 \\
\hline Croatia & 10.6 & 4.9 & -5.7 & 6 \\
\hline Lithuania & 3.5 & 5.4 & 1.9 & 20 \\
\hline Moldova & 5.9 & 5.2 & -0.7 & 16 \\
\hline China & 35.5 & 9.9 & -25.6 & 1 \\
\hline Chinese Taipei* & 8.3 & 6.4 & -1.9 & 13 \\
\hline Armenia & 2.9 & 3.0 & 0.1 & 17 \\
\hline Macedonia FYR & 14.4 & 7.9 & -6.5 & 5 \\
\hline Nepal & 16.6 & 13.9 & -2.7 & 10 \\
\hline Cambodia & 16.4 & 14.3 & -2.1 & 12 \\
\hline Saudi Arabia & 12.1 & 5.2 & -6.9 & 4 \\
\hline Viet Nam & 16.5 & 16.8 & 0.3 & 18 \\
\hline Kingdom of Tonga & NA & 16.8 & NA & NA \\
\hline
\end{tabular}

Note: NA: Not available, Base year is the year of 1st Working Party meeting. Due to data availability, some countries may not match with exact year. Rank 1 implies maximum decline in tariff rate.

* Chinese Taipei referred to in the United Nations as Taiwan Province of China.

Source: UNCTAD TRAINS database.

Table A7. Descriptive statistics of 23 newly acceded WTO members

\begin{tabular}{|lccrrrr|}
\hline & Year & \# Observations & Mean & Std. Dev. & Min & Max \\
\hline GDP per capita(current \$US) & 2005 & 23 & 4295.93 & 4283.04 & 270.70 & 15291.50 \\
Trade/GDP ratio & 1995 & 23 & 86.60 & 35.41 & 43.90 & 198.80 \\
& 2005 & 23 & 109.28 & 36.83 & 49.00 & 175.00 \\
MFN Tariff Rates & 1995 & 23 & 11.92 & 7.59 & 1.60 & 35.50 \\
& 2005 & 23 & 8.20 & 4.12 & 3.00 & 16.80 \\
Shares of merchandise exports & 1995 & 23 & 0.29 & 0.74 & 0.00 & 2.88 \\
(\% of World) & 2005 & 23 & 0.52 & 1.56 & 0.00 & 7.28 \\
Shares of merchandise imports & 1995 & 23 & 0.26 & 0.64 & 0.00 & 2.53 \\
(\% of World) & 2005 & 23 & 0.43 & 1.29 & 0.00 & 6.13 \\
\hline
\end{tabular}

Note: Author's calculation.

Source: UNCTAD and World Bank. 
Table A8. List of commitments (areas and paragraphs), working party meetings and number of members

\begin{tabular}{|c|c|c|c|c|}
\hline & $\begin{array}{c}\text { \# areas of } \\
\text { commitments in } \\
\text { Working Party } \\
\text { Reports }\end{array}$ & $\begin{array}{c}\text { \# paragraphs of } \\
\text { commitments in } \\
\text { Working Party } \\
\text { Reports }\end{array}$ & $\begin{array}{c}\text { \#Working Party } \\
\text { Meetings }\end{array}$ & $\begin{array}{c}\text { \# Working Party } \\
\text { Members }\end{array}$ \\
\hline Ecuador & 17 & 21 & 9 & 21 \\
\hline Macedonia, FYR & 19 & 24 & 5 & 23 \\
\hline Panama & 19 & 24 & 5 & 34 \\
\hline Mongolia & 20 & 17 & 5 & 17 \\
\hline Latvia & 20 & 22 & 6 & 24 \\
\hline Nepal & 20 & 25 & 3 & 23 \\
\hline Estonia & 21 & 24 & 8 & 21 \\
\hline Kyrgyz Republic & 21 & 29 & 6 & 15 \\
\hline Bulgaria & 22 & 26 & 9 & 22 \\
\hline Croatia & 22 & 27 & 6 & 19 \\
\hline Lithuania & 22 & 28 & 5 & 27 \\
\hline Albania & 22 & 29 & 9 & 16 \\
\hline Georgia & 23 & 29 & 3 & 21 \\
\hline Jordan & 23 & 29 & 5 & 32 \\
\hline Chinese Taipei* & 23 & 63 & 11 & 48 \\
\hline Oman & 24 & 26 & 6 & 31 \\
\hline Moldova & 24 & 28 & 5 & 25 \\
\hline Cambodia & 24 & 29 & 5 & 15 \\
\hline Armenia & 25 & 39 & 5 & 30 \\
\hline Saudi Arabia & 26 & 59 & 12 & 57 \\
\hline China & 27 & 82 & 41 & 62 \\
\hline Tonga & 29 & 32 & 3 & 13 \\
\hline Viet Nam & 30 & 70 & 14 & 43 \\
\hline Mean & 23 & 34 & 8 & 28 \\
\hline Median & 22 & 28 & 6 & 23 \\
\hline Std. Dev & 3.18 & 17.13 & 7.73 & 13.24 \\
\hline Min & 17 (Ecuador) & 17 (Mongolia) & 3 (Nepal and Georgia) & 13 (Kyrgyz Republic) \\
\hline Max & 30 (Viet Nam) & 82 (China) & 41 (China) & 62 (China) \\
\hline
\end{tabular}

Note: Author's calculation. Ascending order of \# areas of commitments in WPRs.

* Chinese Taipei referred to in the United Nations as Taiwan Province of China.

Source: Technical Note on the Accession Process, WT/ACC/10/Rev.2, 22 October 2004, and http://www.wto.org/ english/thewto_e/acc_e/acc_e.htm 


\begin{tabular}{|c|c|}
\hline Index of Economic Freedom (EFI) & $\begin{array}{l}\text { Economic freedom is defined as the absence of government coercion or constraint } \\
\text { on the production, distribution, or consumption of goods and services beyond the } \\
\text { extent necessary for citizens to protect and maintain liberty itself. In other words, } \\
\text { people are free to work, produce, consume, and invest in the ways they feel } \\
\text { are most productive. To measure economic freedom and rate each country, } \\
\text { the authors of the Index study } 50 \text { independent economic variables. These } \\
\text { variables fall into } 10 \text { broad categories, or factors, of economic freedom. In } \\
\text { the Index of Economic Freedom, all } 0 \text { factors are equally important to the level } \\
\text { of economic freedom in any country. Thus, to determine a country's overall } \\
\text { score, the factors are weighted equally. The scales run from } 1 \text { to } 5 \text { : a score of } 1 \\
\text { signifies an economic environment or set of policies that are most conducive } \\
\text { to economic freedom, while a score of } 5 \text { signifies a set of policies that are least } \\
\text { conducive to economic freedom. }\end{array}$ \\
\hline (TD) Trade & $\begin{array}{l}\text { Trade policy is a key factor in measuring economic freedom. The degree to } \\
\text { which government hinders access to and the free flow of foreign commerce } \\
\text { can have a direct bearing on the ability of individuals to pursue their } \\
\text { economic goals. The factors are: Weighted average tariff rate, Non-tariff } \\
\text { barriers, Corruption in the customs service. }\end{array}$ \\
\hline (FB) Fiscal Burden & $\begin{array}{l}\text { To measure the fiscal burden a government imposes on its citizens, the } \\
\text { authors examined both marginal tax rates and the year-to-year change in } \\
\text { the level of government expenditures as a percent of gross domestic product } \\
\text { (GDP). The factors are: Top marginal income tax rate, Top marginal corporate } \\
\text { tax rate, Year-to-year change in government expenditures, as a percent of } \\
\text { GDP. }\end{array}$ \\
\hline (GI) Government intervention & $\begin{array}{l}\text { This factor measures government's direct use of scarce resources for its own } \\
\text { purposes and government's control over resources through ownership. } \\
\text { The measure comprises both government consumption and government } \\
\text { production. The factors are Government consumption as a percentage of } \\
\text { the economy, Government ownership of businesses and industries, Share } \\
\text { of government revenues from state-owned enterprises and Government } \\
\text { ownership of property, Economic output produced by the government. }\end{array}$ \\
\hline (MP) Monetary Policy & $\begin{array}{l}\text { The value of a country's currency is shaped largely by its monetary policy. } \\
\text { With a stable monetary policy, people can rely on market prices for the } \\
\text { foreseeable future. Hence, investment, savings, and other longer-term plans } \\
\text { are easier to make, and individuals enjoy greater economic freedom. The } \\
\text { factors are: Weighted average inflation rate from } 1995 \text { to } 2004 \text {. }\end{array}$ \\
\hline (FI) Foreign investment & $\begin{array}{l}\text { Restrictions on foreign investment limit the inflow of capital and thus hamper } \\
\text { economic freedom. By contrast, little or no restriction of foreign investment } \\
\text { enhances economic freedom because foreign investment provides funds } \\
\text { for economic expansion. For this factor, the more restrictions a country } \\
\text { imposes on foreign investment, the lower its level of economic freedom and } \\
\text { the higher its score. The factors are: Foreign investment code, Restrictions } \\
\text { on foreign ownership of business, Restrictions on industries and companies } \\
\text { open to foreign investors, Restrictions and performance requirements on } \\
\text { foreign companies, Foreign ownership of land, Equal treatment under the } \\
\text { law for both foreign and domestic companies, Restrictions on repatriation of } \\
\text { earnings, Restrictions on capital transactions, Availability of local financing } \\
\text { for foreign companies }\end{array}$ \\
\hline
\end{tabular}


Table A9. (continued)

\begin{tabular}{|c|c|}
\hline (BK) Banking & $\begin{array}{l}\text { In most countries, banks provide the essential financial services that facilitate } \\
\text { economic growth; they lend money to start businesses, purchase homes, } \\
\text { and secure credit that is used to buy durable consumer goods, in addition } \\
\text { to furnishing a safe place in which individuals can store their earnings. The } \\
\text { more banks are controlled by the government, the less free they are to engage } \\
\text { in these activities. Hence, heavy bank regulation reduces opportunities and } \\
\text { restricts economic freedom; therefore, the more a government restricts its } \\
\text { banking sector, the lower its level of economic freedom and the higher its } \\
\text { score. The factors are: Government ownership of financial institutions, } \\
\text { Restrictions on the ability of foreign banks to open branches and subsidiaries, } \\
\text { Government influence over the allocation of credit, Government regulations } \\
\text { that inhibit financial activity, Freedom to offer all types of financial services, } \\
\text { securities, and insurance policies. }\end{array}$ \\
\hline (WP) Wages and prices & $\begin{array}{l}\text { In a free-market economy, prices allocate resources to their highest use. A firm } \\
\text { that needs more employees may signal this need to the market by offering a } \\
\text { higher wage; an individual who greatly values a home on the market offers } \\
\text { a higher price to purchase it. Prices also act as signals to producers and } \\
\text { consumers by conveying information that it otherwise would be prohibitively } \\
\text { costly to obtain. The factors are: Minimum wage laws, Freedom to set prices } \\
\text { privately without government influence, Government price controls, Extent } \\
\text { to which government price controls are used, Government subsidies to } \\
\text { businesses that affect prices. }\end{array}$ \\
\hline (PR) Property Rights & $\begin{array}{l}\text { The ability to accumulate private property is the main motivating force in a } \\
\text { market economy, and the rule of law is vital to a fully functioning free market } \\
\text { economy. Secure property rights give citizens the confidence to undertake } \\
\text { commercial activities, save their income, and make long-term plans because } \\
\text { they know that their income and savings are safe from expropriation. This } \\
\text { factor examines the extent to which the government protects private property } \\
\text { by enforcing the laws and how safe private property is from expropriation. } \\
\text { The less protection private property receives, the lower a country's level } \\
\text { of economic freedom and the higher its score. The factors are: Freedom } \\
\text { from government influence over the judicial system, Commercial code } \\
\text { defining contracts, Sanctioning of foreign arbitration of contract disputes, } \\
\text { Government expropriation of property, Corruption within the judiciary, } \\
\text { Delays in receiving judicial decisions and/or enforcement, Legally granted } \\
\text { and protected private property. }\end{array}$ \\
\hline (RE) Regulation & $\begin{array}{l}\text { Regulations and restrictions are in effect a form of taxation that makes it } \\
\text { difficult for entrepreneurs to create and/or maintain new businesses. In } \\
\text { some countries, government officials frown on any private-sector initiatives; } \\
\text { in a few, they even make them illegal. Although many regulations hinder } \\
\text { businesses, the most important are associated with licensing new companies } \\
\text { and businesses. The factors are: Licensing requirements to operate a business, } \\
\text { Ease of obtaining a business license, Corruption within the bureaucracy; } \\
\text { Labor regulations, such as established workweeks, paid vacations, and } \\
\text { parental leave, as well as selected labor regulations; Environmental, } \\
\text { consumer safety, and worker health regulations; Regulations that impose a } \\
\text { burden on business. }\end{array}$ \\
\hline (IM) Informal market & $\begin{array}{l}\text { Informal markets are the directresult of somekind of governmentintervention } \\
\text { in the marketplace. An informal market activity is one that the government } \\
\text { has taxed heavily, regulated in a burdensome manner, or simply outlawed } \\
\text { in the past. This factor captures the effects of government interventions that } \\
\text { are not always fully measured elsewhere. The factors are: Smuggling, Piracy } \\
\text { of intellectual property in the informal market, Agricultural production } \\
\text { supplied on the informal market, Manufacturing supplied on the informal } \\
\text { market, Services supplied on the informal market, Transportation supplied } \\
\text { on the informal market, Labor supplied on the informal market. }\end{array}$ \\
\hline
\end{tabular}

Source: http://www.heritage.org/research/features/index/chapters/pdfs/Index2006_Chap5.pdf 
Table A10. Descriptive statistics of the Index of Economic Freedom (EFI)

\begin{tabular}{|lcccccc|}
\hline & $\begin{array}{c}\text { Observations, } \\
\text { Cross country }\end{array}$ & $\begin{array}{c}\text { Observations, } \\
\text { Panel }\end{array}$ & Mean & $\begin{array}{c}\text { Standard } \\
\text { deviation }\end{array}$ & Min & Max \\
\hline $\begin{array}{l}\text { Developing country GATT } \\
\text { members }\end{array}$ & 80 & 744 & 1.73 & 0.58 & 0.00 & 3.25 \\
WTO members & 20 & 181 & 1.85 & 0.48 & 0.90 & 3.32 \\
WTO members-GATT & & & & & & \\
Article XXVI:5(c) & 9 & 76 & 1.71 & 0.71 & 0.50 & 3.25 \\
\hline
\end{tabular}

Notes: The Index of Economic Freedom includes 10 indicators: trade, fiscal burden, government intervention, monetary policy, foreign investment, banking, wages and prices, property rights, regulation, informal market. The higher score implies higher economic freedom.

Source: The Index of Economic Freedom is from the Heritage Foundation and WTO accession year is from WTO accession documents.

Table A11. PRS Group-International Country Risk Guide (ICRG)

\begin{tabular}{|c|c|}
\hline $\begin{array}{l}\text { International Country Risk Guide } \\
\text { (ICRG) }\end{array}$ & $\begin{array}{l}\text { The International Country Risk Guide (ICRG) rating comprises } 22 \text { variables in } \\
\text { three subcategories of risk: political, financial, and economic. A separate index } \\
\text { is created for each of the subcategories. The Political Risk index is based on } 100 \\
\text { points, Financial Risk on } 50 \text { points, and Economic Risk on } 50 \text { points. The total } \\
\text { points from the three indices are divided by two to produce the weights for } \\
\text { inclusion in the composite country risk score. The composite scores, ranging } \\
\text { from zero to 100, are then broken into categories from Very Low Risk ( } 80 \text { to } 100 \\
\text { points) to Very High Risk (zero to } 49.5 \text { points).The ICRG staff collects political } \\
\text { information and financial and economic data, converting these into risk points } \\
\text { for each individual risk component on the basis of a consistent pattern of } \\
\text { evaluation. The political risk assessments are made on the basis of subjective } \\
\text { analysis of the available information, while the financial and economic risk } \\
\text { assessments are made solely on the basis of objective data. In addition to the } 22 \\
\text { individual ratings, the ICRG model also produces a rating for each of the three } \\
\text { risk factor groups plus an overall score for each country. }\end{array}$ \\
\hline Investment profile (IP): & $\begin{array}{l}\text { This is an assessment of factors affecting the risk to investment that are not } \\
\text { covered by other political, economic and financial risk components. The risk } \\
\text { rating assigned is the sum of three subcomponents, each with a maximum score } \\
\text { of four points and a minimum score of } 0 \text { points. A score of } 4 \text { points equates to } \\
\text { Very Low Risk and a score of } 0 \text { points to Very High Risk. The subcomponents are: } \\
\text { Contract Viability/Expropriation, Profits Repatriation, and Payment Delays. }\end{array}$ \\
\hline Law and Order (LO): & $\begin{array}{l}\text { Law and Order are assessed separately, with each sub-component comprising } \\
\text { zero to three points. The Law sub-component is an assessment of the strength } \\
\text { and impartiality of the legal system, while the Order sub-component is an } \\
\text { assessment of popular observance of the law. Thus, a country can enjoy a high } \\
\text { rating - } 3 \text { - in terms of its judicial system, but a low rating - } 1 \text { - if it suffers } \\
\text { from a very high crime rate of if the law is routinely ignored without effective } \\
\text { sanction (for example, widespread illegal strikes). }\end{array}$ \\
\hline Bureaucratic Quality (BQ): & $\begin{array}{l}\text { The institutional strength and quality of the bureaucracy is another shock } \\
\text { absorber that tends to minimize revisions of policy when governments } \\
\text { change. Therefore, high points are given to countries where the bureaucracy } \\
\text { has the strength and expertise to govern without drastic changes in policy } \\
\text { or interruptions in government services. In these low-risk countries, the } \\
\text { bureaucracy tends to be somewhat autonomous from political pressure and to } \\
\text { have an established mechanism for recruitment and training. Countries that } \\
\text { lack the cushioning effect of a strong bureaucracy receive low points because a } \\
\text { change in government tends to be traumatic in terms of policy formulation and } \\
\text { day-to-day administrative functions. }\end{array}$ \\
\hline ICRG Index & It is a simple average of IP, $\mathrm{LO}$ and $\mathrm{BQ}$ from the existing sample \\
\hline
\end{tabular}

Source: http://www.prsgroup.com/commonhtml/methods.html 
Table A12. Descriptive statistics of International Country Risk Guide (ICRG) database

\begin{tabular}{|lcccccc|}
\hline & $\begin{array}{c}\text { Observations, } \\
\text { Cross country }\end{array}$ & $\begin{array}{c}\text { Observations, } \\
\text { Panel }\end{array}$ & Mean & $\begin{array}{c}\text { Standard } \\
\text { deviation }\end{array}$ & Min & Max \\
\hline $\begin{array}{l}\text { Developing country GATT } \\
\text { members }\end{array}$ & 68 & 680 & 4.163 & 1.026 & 0.666 & 6.666 \\
WTO members & 14 & 122 & 4.573 & 0.891 & 2.611 & 6.166 \\
$\begin{array}{l}\text { WTO members- GATT } \\
\text { Article XXVI:5(c) }\end{array}$ & 8 & 80 & 3.908 & 1.127 & 2.000 & 6.166 \\
\hline
\end{tabular}

Notes: The ICRG index includes 3 indicators: Investment profile, law and order, and bureaucratic quality.

The higher score implies less risk.

Source: PRS Group ICRG database and WTO accession year is from WTO accession documents.

Table A13. Correlation among EFI indicators

\begin{tabular}{|c|c|c|c|c|c|c|c|c|c|c|c|}
\hline & EFI & TD & FB & GI & MP & FI & BK & WP & PR & RE & IM \\
\hline EFI & 1 & & & & & & & & & & \\
\hline $\mathrm{TD}$ & 0.593 & 1 & & & & & & & & & \\
\hline FB & 0.448 & 0.333 & 1 & & & & & & & & \\
\hline GI & 0.443 & 0.257 & 0.130 & 1 & & & & & & & \\
\hline MP & 0.421 & $\underline{-0.010}$ & $0.069^{*}$ & $\underline{0.011}$ & 1 & & & & & & \\
\hline FI & 0.693 & 0.381 & 0.226 & 0.294 & 0.094 & 1 & & & & & \\
\hline BK & 0.757 & 0.407 & 0.291 & 0.305 & 0.189 & 0.607 & 1 & & & & \\
\hline WP & 0.688 & 0.273 & 0.237 & 0.320 & 0.188 & 0.545 & 0.566 & 1 & & & \\
\hline PR & 0.717 & 0.348 & 0.198 & 0.136 & 0.143 & 0.483 & 0.497 & 0.417 & 1 & & \\
\hline $\mathrm{RE}$ & 0.741 & 0.361 & 0.214 & 0.145 & 0.209 & 0.504 & 0.514 & 0.492 & 0.698 & 1 & \\
\hline IM & 0.700 & 0.297 & 0.241 & 0.142 & 0.230 & 0.355 & 0.439 & 0.409 & 0.651 & 0.604 & 1 \\
\hline
\end{tabular}

Note: *statistically significant at 5\%-level, and all other coefficients are statistically significant at $1 \%$-level, underline implies coefficient is not significant.

Sample consists of Developing country GATT/WTO members.

Source: The Index of Economic Freedom is from the Heritage Foundation; log (real GDP per capita) from the World Bank. 
Table A14. Correlation of GDP per capita with EFI indicators

\begin{tabular}{|lc|}
\hline & GDPpc \\
\hline (EFI) Index of Economic Freedom & 0.657 \\
(TD) Trade & 0.355 \\
(FB) Fiscal burden & 0.301 \\
(GI) Government intervention & 0.168 \\
(MP) Monetary policy & 0.174 \\
(FI) Foreign investment & 0.431 \\
(BK) Banking & 0.468 \\
(WP) Wages and prices & 0.360 \\
(PR) Property rights & 0.564 \\
(RE) Regulation & 0.629 \\
(IM) Informal market & 0.572 \\
\hline
\end{tabular}

Note: All coefficients are statistically significant at $1 \%$-level.

GDP is in PPP (constant 2000 international \$) value. Acronyms are in parentheses.

Sample consists of Developing country GATT/WTO members.

Source: The Index of Economic Freedom is from the Heritage Foundation; log (real GDP per capita) from the World Bank.

Table A15. Correlation among International Country Risk Guide (ICRG) indicators

\begin{tabular}{|lcccc|}
\hline & ICRGI & IP & LO & BQ \\
\hline International Country Risk Guide Index (ICRGI) & 1 & & & \\
(IP) Investment Profile & 0.859 & 1 & & \\
(LO) Law and Order & 0.623 & 0.219 & 1 & 1 \\
(BQ) Bureaucratic Quality & 0.590 & 0.285 & 0.310 & 1 \\
\hline
\end{tabular}

Note: All coefficients are statistically significant at $1 \%$-level.

Sample consists of Developing country GATT/WTO members.

Source: PRS Group ICRG database.

Table A16. Correlation of GDP per capita with ICRG index indicators

\begin{tabular}{|l|c|}
\hline \multicolumn{2}{|c|}{ GDPpc } \\
\hline International Country Risk Guide Index (ICRGI) & 0.548 \\
(IP) Investment Profile & 0.365 \\
(LO) Law and Order & 0.366 \\
(BQ) Bureaucratic Quality & 0.561 \\
\hline
\end{tabular}

Note: All coefficients are statistically significant at 1\%-level.

Sample consists of Developing country GATT/WTO members.

Source: PRS Group ICRG database. 
Table A17. List of countries in sample for empirical analysis

\begin{tabular}{|c|c|c|c|}
\hline Country & Country & Country & Country \\
\hline Angola $^{1}$ & Djibouti $^{1}$ & Lithuania & Papua New Guinea $^{1}$ \\
\hline Albania & Dominican Republic & Latvia & Poland \\
\hline Argentina & Ecuador & Morocco & Paraguay \\
\hline Armenia & Egypt, Arab Rep. & Moldova & Romania \\
\hline Burundi & Estonia & Madagascar & Rwanda \\
\hline Benin & Gabon & Mexico & Saudi Arabia \\
\hline Burkina Faso & Georgia & Macedonia, FYR & Senegal \\
\hline Bangladesh & Ghana & Mali $^{1}$ & El Salvador \\
\hline Bulgaria & Guinea $^{1}$ & Myanmar & Suriname \\
\hline Bahrain $^{1}$ & Guinea-Bissau $^{1}$ & Mongolia & Slovak Republic \\
\hline Belize & Guatemala & Mozambique $^{1}$ & Swaziland ${ }^{1}$ \\
\hline Bolivia & Guyana & Mauritania & Chad \\
\hline Brazil & Honduras & Mauritius & Togo \\
\hline Barbados & Croatia & Malawi & Thailand \\
\hline Botswana & Hungary & Malaysia & Trinidad and Tobago \\
\hline Central African Republic & Indonesia & Namibia $^{1}$ & Tunisia \\
\hline Chile & India & Niger & Turkey \\
\hline China & Jamaica & Nigeria & Tanzania (United Rep) \\
\hline Cote d'Ivoire & Jordan & Nicaragua & Uganda \\
\hline Cameroon & Kenya & Nepal & Uruguay \\
\hline Congo, Rep. & Kyrgyz Republic & Oman & Venezuela, BR \\
\hline Colombia & Cambodia & Pakistan & South Africa \\
\hline Costa Rica & Korea, Rep. & Panama & Congo, Dem. Rep. \\
\hline Cuba & Sri Lanka & Peru & Zambia \\
\hline Czech Republic & Lesotho & Philippines & Zimbabwe \\
\hline
\end{tabular}

Note: Countries in BOLD are not in the ICRG database. $\quad{ }^{1}$ GATT Article XXVI:5(c) countries in sample.

Source: Heritage Foundation for the Index of Economic Freedom, and PRS-Group for the International Country Risk Guide database. 
Table A18. OLS estimation - WTO accession impact on domestic economic policy and institution

\begin{tabular}{|c|c|c|c|c|c|c|}
\hline & \multicolumn{6}{|c|}{ Dependent variable: Index of Economic Freedom } \\
\hline & Col.1 & Col.2 & Col.3 & Col.4 & Col.5 & Col.6 \\
\hline \multirow[t]{2}{*}{ WTO accession year(t) } & $0.138^{*}$ & 0.104 & 0.103 & & & \\
\hline & $(0.091)$ & $(0.094)$ & $(0.094)$ & & & \\
\hline \multirow[t]{2}{*}{ WTO accession year $(\mathrm{t} 0)$} & & & & 0.046 & 0.041 & 0.031 \\
\hline & & & & $(0.086)$ & $(0.087)$ & $(0.088)$ \\
\hline \multirow[t]{2}{*}{ WTO accession year after $\left(\mathrm{t} 0+\mathrm{t}^{*}\right)$} & & & & $0.134^{* *}$ & $0.132^{*}$ & $0.123^{*}$ \\
\hline & & & & $(0.097)$ & $(0.100)$ & $(0.100)$ \\
\hline \multirow[t]{2}{*}{ Log (real GDP per capita) ${ }_{\mathrm{t}-1}$} & $0.282^{* * *}$ & $0.282^{* * *}$ & $0.282^{* * *}$ & $0.189^{* * *}$ & $0.292^{* * *}$ & $0.282^{* * *}$ \\
\hline & $(0.029)$ & $(0.029)$ & $(0.029)$ & $(0.030)$ & $(0.030)$ & (0.029) \\
\hline Country effects & $\mathrm{N}$ & $\mathrm{N}$ & $\mathrm{N}$ & $\mathrm{N}$ & $\mathrm{N}$ & $\mathrm{N}$ \\
\hline Year effects & $\mathrm{N}$ & $\mathrm{N}$ & Y & $\mathrm{N}$ & $\mathrm{N}$ & Y \\
\hline Time trend & $\mathrm{N}$ & Y & Y & $\mathrm{N}$ & Y & Y \\
\hline \multirow[t]{2}{*}{ Constant } & -0.232 & -0.403 & $-0.381^{*}$ & -0.300 & $-0.400^{* *}$ & $-0.380^{* *}$ \\
\hline & $(0.205)$ & $(0.209)$ & $(0.214)$ & $(0.210)$ & $(0.209)$ & $(0.210)$ \\
\hline \#Observations & 906 & 906 & 906 & 906 & 906 & 906 \\
\hline \#Countries & 98 & 98 & 98 & 98 & 98 & 98 \\
\hline R-squared & 0.439 & 0.450 & 0.415 & 0.442 & 0.450 & 0.451 \\
\hline F-statistics & 51.03 & 37.81 & 12.67 & 35.19 & 29.05 & 13.64 \\
\hline
\end{tabular}

Notes: The Index of Economic Freedom includes 10 indicators: trade, fiscal burden, government intervention, monetary policy, foreign investment, banking, wages and prices, property rights, regulation, informal market. The higher score implies higher economic freedom.

Treatment Group: The WTO acceded members.

WTO membership year ( $\mathrm{t}$ ): Country gets 1 if it becomes a WTO member, and continues to be 1 for the rest of the sample time points.

WTO accession year (t0): It takes 1 for WTO accession year, and rest of the time points is zero.

WTO accession year after $\left(\mathrm{t} 0+\mathrm{t}^{*}\right)$ : It takes 1 for the year after WTO accession, and continues to be 1 for the rest of the sample points.

Control Group: Developing country GATT members.

Robust standard errors are (in parentheses) adjusted for clustering in all countries. ${ }^{* *}$ implies significance at the 1 per cent level; ${ }^{* *}$ at the 5 per cent level; and ${ }^{*}$ at the 10 per cent level.

Source: The Index of Economic Freedom is from the Heritage Foundation, WTO accession year is from WTO accession documents; log (real GDP per capita) from the World Bank. 
Table A19. FGLS estimation - WTO accession impact on domestic economic policy and institution

\begin{tabular}{|c|c|c|c|c|c|c|}
\hline & \multicolumn{6}{|c|}{ Dependent variable: Index of Economic Freedom } \\
\hline & Col.1 & Col.2 & Col.3 & Col.4 & Col.5 & Col.6 \\
\hline \multirow[t]{2}{*}{ WTO accession year(t) } & $0.124^{* * *}$ & $0.094^{* * *}$ & $0.091^{* * *}$ & & & \\
\hline & $(0.040)$ & $(0.041)$ & $(0.041)$ & & & \\
\hline \multirow[t]{2}{*}{ WTO accession year $(\mathrm{t} 0)$} & & & & $0.091^{* * *}$ & $0.071^{* *}$ & $0.079^{* *}$ \\
\hline & & & & $(0.041)$ & $(0.042)$ & $(0.042)$ \\
\hline \multirow[t]{2}{*}{ WTO accession year after $\left(\mathrm{t} 0+\mathrm{t}^{*}\right)$} & & & & $0.189^{* * *}$ & $0.149^{* * *}$ & $0.141^{* * *}$ \\
\hline & & & & $(0.052)$ & $(0.052)$ & $(0.052)$ \\
\hline \multirow{2}{*}{$\log$ (real GDP per capita) $_{\mathrm{t}-1}$} & $0.281^{* * *}$ & $0.281^{* * *}$ & $0.284^{* * *}$ & $0.287^{* * *}$ & $0.281^{* * *}$ & $0.282^{* * *}$ \\
\hline & $(0.018)$ & $(0.017)$ & $(0.019)$ & $(0.019)$ & $(0.017)$ & $(0.017)$ \\
\hline Country effects & $\mathrm{N}$ & $\mathrm{N}$ & $\mathrm{N}$ & $\mathrm{N}$ & $\mathrm{N}$ & $\mathrm{N}$ \\
\hline Year effects & $\mathrm{N}$ & $\mathrm{N}$ & Y & $\mathrm{N}$ & $\mathrm{N}$ & $\mathrm{Y}$ \\
\hline Time trend & $\mathrm{N}$ & Y & Y & $\mathrm{N}$ & $\mathrm{Y}$ & $\mathrm{Y}$ \\
\hline \multirow[t]{2}{*}{ Constant } & $-0.250^{* * *}$ & $-0.416^{* * *}$ & $-0.432^{* * *}$ & $-0.303^{* * *}$ & $-0.408^{* * *}$ & $-0.425^{* * *}$ \\
\hline & (0.131) & $(0.124)$ & $(0.131)$ & $(0.130)$ & $(0.124)$ & $(0.124)$ \\
\hline \#Observations & 906 & 906 & 906 & 906 & 906 & 906 \\
\hline \#Countries & 98 & 98 & 98 & 98 & 98 & 98 \\
\hline $\mathrm{AR}(1)$ & -0.805 & -0.782 & -0.780 & -0.802 & -0.780 & -0.778 \\
\hline Log likelihood & 272.7 & 265.3 & 266.8 & 273.1 & 265.0 & 266.7 \\
\hline Wald Statistics & 269.7 & 332.3 & 343.8 & 278.6 & 337.9 & 349.8 \\
\hline
\end{tabular}

Notes: The Index of Economic Freedom includes 10 indicators: trade, fiscal burden, government intervention, monetary policy, foreign investment, banking, wages and prices, property rights, regulation, informal market. The higher score implies higher economic freedom.

Treatment Group: The WTO acceded members.

WTO membership year (t): Country gets 1 if it becomes a WTO member, and continues to be 1 for the rest of the sample time points.

WTO accession year (t0): It takes 1 for WTO accession year, and rest of the time points is zero.

WTO accession year after $\left(\mathrm{t} 0+\mathrm{t}^{*}\right)$ : It takes 1 for the year after WTO accession, and continues to be 1 for the rest of the sample points.

Control Group: Developing country GATT members.

GLS model uses linear panel model using feasible generalized least squares. The model specification permits AR(1) correlation over time, and specifies that each group has a different AR(1) process for different cross-section units. Standard errors are (in parentheses)

Z-statistics ${ }^{* * *}$ implies significance at the 1 per cent level;** at the 5 per cent level; and * at the 10 per cent level.

Source: The Index of Economic Freedom is from the Heritage Foundation, WTO accession year is from WTO accession documents; log (real GDP per capita) from the World Bank. 
Table A20. Fixed effects estimation - WTO accession impact on domestic economic policy and institution

\begin{tabular}{|c|c|c|c|c|c|c|}
\hline & \multicolumn{6}{|c|}{ Dependent variable: Index of Economic Freedom } \\
\hline & Col.1 & Col.2 & Col.3 & Col.4 & Col.5 & Col.6 \\
\hline \multirow[t]{2}{*}{ WTO accession year(t) } & $0.117^{* * *}$ & $0.119^{* *}$ & $0.111^{* * *}$ & & & \\
\hline & $(0.046)$ & $(0.049)$ & $(0.050)$ & & & \\
\hline \multirow[t]{2}{*}{ WTO accession year $(\mathrm{t} 0)$} & & & & $0.064^{*}$ & 0.067 & 0.061 \\
\hline & & & & $(0.039)$ & $(0.041)$ & $(0.041)$ \\
\hline \multirow[t]{2}{*}{ WTO accession year after $\left(\mathrm{t} 0+\mathrm{t}^{*}\right)$} & & & & $0.133^{* * *}$ & $0.131^{* * *}$ & $0.134^{* * *}$ \\
\hline & & & & $(0.054)$ & $(0.057)$ & $(0.059)$ \\
\hline \multirow{2}{*}{ Log (real GDP per capita) ${ }_{t-1}$} & $1.056^{* * *}$ & $0.990^{* * *}$ & $1.055^{* * *}$ & $1.027^{* * *}$ & $0.970^{* * *}$ & $0.980^{* * *}$ \\
\hline & $(0.183)$ & $(0.224)$ & $(0.222)$ & $(0.186)$ & $(0.227)$ & $(0.224)$ \\
\hline Country effects & Y & Y & Y & $\mathrm{Y}$ & Y & Y \\
\hline Year fixed effects & $\mathrm{N}$ & $\mathrm{N}$ & Y & $\mathrm{N}$ & $\mathrm{N}$ & Y \\
\hline Time trend & $\mathrm{N}$ & Y & Y & $\mathrm{N}$ & Y & Y \\
\hline \multirow[t]{2}{*}{ Constant } & $-6.328^{* * *}$ & $-4.936^{* * *}$ & $-4.372^{* * *}$ & $-6.194^{* * *}$ & $-4.864^{* * *}$ & $-4.869^{* * *}$ \\
\hline & (1.293) & $(1.560)$ & $(1.545)$ & $(1.314)$ & $(1.527)$ & $(1.626)$ \\
\hline \#Observations & 906 & 906 & 906 & 906 & 906 & 906 \\
\hline \#Countries & 98 & 98 & 98 & 98 & 98 & 98 \\
\hline Breusch-Pagan LM test $\chi^{2}(1)$ & $1937.32^{* * *}$ & & & & & \\
\hline Hausman Specification Test $\chi^{2}(2)$ & $16.42^{* * *}$ & & & & & \\
\hline R-squared & 0.435 & 0.439 & 0.439 & 0.435 & 0.407 & 0.439 \\
\hline F-statistics & 35.73 & 23.51 & 9.16 & 24.94 & 17.99 & 8.65 \\
\hline
\end{tabular}

Notes: The Index includes 10 indicators: trade, fiscal burden, government intervention, monetary policy, foreign investment, banking, wages and prices, property rights, regulation, informal market. The higher score implies higher economic freedom.

The Breusch-Pagan LM statistic tests the random effect model versus the pooling OLS. The Hausman specification statistic tests the fixed-effect model versus the random effect model. WTO membership year ( $t$ ): Country gets 1 if becomes WTO member, and continues to be 1 for the rest of the sample time points.

WTO accession year ( $\mathrm{t} 0$ ): It takes 1 for WTO accession year, and rest of the time points is zero.

WTO accession year after $\left(\mathrm{t} 0+\mathrm{t}^{*}\right)$ : It takes 1 for the year after WTO accession, and continues to be 1 for the rest of the sample points.

Treatment Group: The WTO acceded members.

Control Group: Developing country GATT members.

Robust standard errors are (in parentheses) adjusted for clustering in all countries. ${ }^{* *}$ implies significance at the 1 per cent level; ${ }^{* *}$ at the 5 per cent level; and * at the 10 per cent level.

Source: The Index of Economic Freedom is from the Heritage Foundation, WTO accession year is from WTO accession documents; log (real GDP per capita) from the World Bank. 
Table A21. OLS estimation - Robustness analysis:

WTO accession impact on domestic economic policy and institution

\begin{tabular}{|c|c|c|c|c|c|c|}
\hline & \multicolumn{6}{|c|}{ Dependent variable: ICRG Index } \\
\hline & Col.1 & Col.2 & Col.3 & Col.4 & Col.5 & Col.6 \\
\hline \multirow[t]{2}{*}{ WTO accession year(t) } & $0.385^{* *}$ & $0.330^{*}$ & $0.340^{*}$ & & & \\
\hline & $(0.198)$ & $(0.202)$ & $(0.203)$ & & & \\
\hline \multirow[t]{2}{*}{ WTO accession year (t0) } & & & & -0.060 & -0.057 & -0.026 \\
\hline & & & & $(0.175)$ & $(0.179)$ & $(0.159)$ \\
\hline \multirow[t]{2}{*}{ WTO accession year after $\left(\mathrm{t} 0+\mathrm{t}^{*}\right)$} & & & & $0.495^{* *}$ & $0.434^{*}$ & $0.429^{*}$ \\
\hline & & & & $(0.221)$ & $(0.227)$ & $(0.231)$ \\
\hline \multirow[t]{2}{*}{$\log$ (real GDP per capita) $_{\mathrm{t}-1}$} & $0.461^{* * *}$ & $0.462^{* * *}$ & $0.461^{* * *}$ & $0.461^{* * *}$ & $0.461^{* * *}$ & $0.453^{* * *}$ \\
\hline & $(0.068)$ & $(0.068)$ & $(0.069)$ & $(0.068)$ & $(0.068)$ & $(0.069)$ \\
\hline Country effects & $\mathrm{N}$ & $\mathrm{N}$ & $\mathrm{N}$ & $\mathrm{N}$ & $\mathrm{N}$ & $\mathrm{N}$ \\
\hline Year effects & $\mathrm{N}$ & $\mathrm{N}$ & $\mathrm{Y}$ & $\mathrm{N}$ & $\mathrm{N}$ & Y \\
\hline Time trend & $\mathrm{N}$ & Y & Y & $\mathrm{N}$ & Y & Y \\
\hline \multirow[t]{2}{*}{ Constant } & $0.943^{* *}$ & 0.433 & 0.118 & $0.945^{* *}$ & 0.455 & 0.128 \\
\hline & $(0.496)$ & $(0.504)$ & $(0.496)$ & $(0.493)$ & $(0.505$ & $(0.497)$ \\
\hline \#Observations & 782 & 782 & 782 & 782 & 782 & 782 \\
\hline \#Countries & 80 & 80 & 80 & 80 & 80 & 80 \\
\hline R-squared & 0.315 & 0.334 & 0.359 & 0.319 & 0.337 & 0.362 \\
\hline F-statistics & 28.54 & 28.1 & 26.64 & 19.73 & 21.36 & 25.36 \\
\hline
\end{tabular}

Notes: The ICRG index includes 3 indicators: Investment profile, law and order, and bureaucratic quality.

The higher score implies less risk.

Treatment Group: The WTO acceded members.

WTO membership year ( $t$ ): Country gets 1 if becomes WTO member, and continues to be 1 for the rest of the sample time points.

WTO accession year (t0): It takes 1 for WTO accession year, and rest of the time points is zero.

WTO accession year after $\left(\mathrm{t} 0+\mathrm{t}^{*}\right)$ : It takes 1 for the year after WTO accession, and continues to be 1 for the rest of the sample points.

Control Group: Developing country GATT members.

Robust standard errors are (in parentheses) adjusted for clustering in all countries. ${ }^{* *}$ implies significance at the 1 per cent level; ${ }^{* *}$ at the 5 per cent level; and * at the 10 per cent level.

Source: The ICRG Index is from PRS Group ICRG database, WTO accession year is from WTO accession documents; $\log$ (real GDP per capita) from the World Bank. 
Table A22. FGLS estimation - Robustness analysis: WTO accession impact on domestic economic policy and institution

\begin{tabular}{|c|c|c|c|c|c|c|}
\hline & \multicolumn{6}{|c|}{ Dependent variable: ICRG Index } \\
\hline & Col.1 & Col.2 & Col.3 & Col.4 & Col.5 & Col.6 \\
\hline \multirow[t]{2}{*}{ WTO accession year $(\mathrm{t})$} & $0.237^{*}$ & 0.142 & 0.115 & & & \\
\hline & $(0.113)$ & $(0.112)$ & $(0.106)$ & & & \\
\hline \multirow[t]{2}{*}{ WTO accession year $(\mathrm{t} 0)$} & & & & 0.039 & -0.015 & -0.031 \\
\hline & & & & $(0.116)$ & $(0.116)$ & $(0.108)$ \\
\hline \multirow[t]{2}{*}{ WTO accession year after $\left(\mathrm{t} 0+\mathrm{t}^{*}\right)$} & & & & $0.563^{* * *}$ & $0.440^{* * *}$ & $0.403^{* * *}$ \\
\hline & & & & $(0.140)$ & $(0.142)$ & $(0.135)$ \\
\hline \multirow[t]{2}{*}{ Log (real GDP per capita) ${ }_{\mathrm{t}-1}$} & $0.482^{* * *}$ & $0.472^{* * *}$ & $0.470^{* * *}$ & $0.473^{* * *}$ & $0.463^{* * *}$ & $0.465^{* * *}$ \\
\hline & $(0.046)$ & $(0.044)$ & $(0.045)$ & $(0.046)$ & $(0.046)$ & $(0.045)$ \\
\hline Country effects & $\mathrm{N}$ & $\mathrm{N}$ & $\mathrm{N}$ & $\mathrm{N}$ & $\mathrm{N}$ & $\mathrm{N}$ \\
\hline Year effects & $\mathrm{N}$ & $\mathrm{N}$ & Y & $\mathrm{N}$ & $\mathrm{N}$ & Y \\
\hline Time trend & $\mathrm{N}$ & Y & Y & $\mathrm{N}$ & Y & Y \\
\hline \multirow[t]{2}{*}{ Constant } & $0.640^{* *}$ & 0.004 & -0.166 & $0.659 * *$ & 0.075 & -0.095 \\
\hline & $(0.329)$ & $(0.338)$ & $(0.339)$ & $(0.334)$ & $(0.344)$ & $(0.343)$ \\
\hline \#Observations & 782 & 782 & 782 & 782 & 782 & 782 \\
\hline \#Countries & 80 & 80 & 80 & 80 & 80 & 80 \\
\hline $\mathrm{AR}(1)$ & -0.781 & -0.778 & -0.806 & -0.791 & -0.788 & -0.811 \\
\hline Log likelihood & -468.964 & -4534 & -388.30 & -454.5 & -441.5 & -378.4 \\
\hline Wald Statistics & 123.960 & 16658 & 28684 & 143.84 & 178.08 & 303.84 \\
\hline
\end{tabular}

Notes: The ICRG index includes 3 indicators: Investment profile, law and order, and bureaucratic quality. The higher score implies less risk.

Treatment Group: The WTO acceded members.

WTO membership year ( $\mathrm{t}$ : Country gets 1 if becomes WTO member, and continues to be 1 for the rest of the sample time points.

WTO accession year ( $\mathrm{t} 0$ ): It takes 1 for WTO accession year, and rest of the time points is zero.

WTO accession year after $\left(\mathrm{t} 0+\mathrm{t}^{*}\right)$ : It takes 1 for the year after WTO accession, and continues to be 1 for the rest of the sample points.

Control Group: Developing country GATT members.

GLS model uses linear panel model using feasible generalized least squares. The model specification permits AR(1) correlation over time, and specifies that each group has a different AR(1) process for different cross-section units. Standard errors are (in parentheses)

Z-statistics ${ }^{* * *}$ implies significance at the 1 per cent level; ${ }^{* *}$ at the 5 per cent level; and ${ }^{*}$ at the 10 per cent level.

Source: The ICRG Index is from PRS Group ICRG database, WTO accession year is from WTO accession documents; $\log$ (real GDP per capita) from the World Bank. 
Table A23. Fixed effects estimation - Robustness analysis: WTO accession impact on domestic economic policy and institution

\begin{tabular}{|c|c|c|c|c|c|c|}
\hline & \multicolumn{6}{|c|}{ Dependent variable: ICRG Index } \\
\hline & Col.1 & Col.2 & Col.3 & Col.4 & Col.5 & Col.6 \\
\hline \multirow[t]{2}{*}{ WTO accession year(t) } & 0.318 & $0.367^{*}$ & $0.362^{*}$ & & & \\
\hline & $(0.213)$ & $(0.201)$ & $(0.195)$ & & & \\
\hline \multirow[t]{2}{*}{ WTO accession year (t0) } & & & & 0.058 & 0.051 & 0.078 \\
\hline & & & & $(0.215)$ & $(0.211)$ & $(0.187)$ \\
\hline \multirow[t]{2}{*}{ WTO accession year after $\left(\mathrm{t} 0+\mathrm{t}^{*}\right)$} & & & & $0.513^{* *}$ & $0.502^{* *}$ & $0.483^{* *}$ \\
\hline & & & & $(0.214)$ & $(0.203)$ & $(0.203)$ \\
\hline \multirow[t]{2}{*}{$\log \left(\right.$ real GDP per capita) ${ }_{t-1}$} & $2.123^{* * *}$ & $1.931^{* * *}$ & 1.799 & $2.043^{* * *}$ & $1.872^{* * *}$ & $1.703^{* * *}$ \\
\hline & $(0.459)$ & $(0.578)$ & $(0.574)$ & $(0.460)$ & $(0.576)$ & $(0.572)$ \\
\hline Country effects & Y & Y & Y & Y & Y & Y \\
\hline Year fixed effects & $\mathrm{N}$ & $\mathrm{N}$ & Y & $\mathrm{N}$ & $\mathrm{N}$ & Y \\
\hline Time trend & $\mathrm{N}$ & Y & Y & $\mathrm{N}$ & Y & Y \\
\hline \multirow[t]{2}{*}{ Constant } & $-16.084^{* * *}$ & $-13.188^{* * *}$ & -13.226 & $-15.532^{* * *}$ & $-12.862^{* * *}$ & -12.879 \\
\hline & $(3.269)$ & $(4.012)$ & $(3.987)$ & $(3.273)$ & $(3.997)$ & $(3.973)$ \\
\hline \#Observations & 782 & 782 & 782 & 782 & 782 & 782 \\
\hline \#Countries & 80 & 80 & 80 & 80 & 80 & 80 \\
\hline Breusch-Pagan LM test $\chi^{2}(1)$ & $1210.021^{* * *}$ & & & & & \\
\hline Hausman Specification Test $\chi^{2}(2)$ & $27.84^{* * *}$ & & & & & \\
\hline R-squared & 0.303 & 0.308 & 0.317 & 0.305 & 0.310 & 0.319 \\
\hline F-statistics & 21.45 & 23.52 & 21.06 & 22.19 & 22.42 & 23.39 \\
\hline
\end{tabular}

Notes: The ICRG index includes 3 indicators: Investment profile, law and order, and bureaucratic quality. The higher score implies less risk.

The Breusch-Pagan LM statistic tests the random effect model versus the pooling OLS. The Hausman specification statistic tests the fixed-effect model versus the random effect model.

Treatment Group: The WTO acceded members.

WTO membership year $(t)$ : Country gets 1 if becomes WTO member, and continues to be 1 for the rest of the sample time points.

WTO accession year ( $\mathrm{t} 0$ ): It takes 1 for WTO accession year, and rest of the time points is zero.

WTO accession year after $\left(\mathrm{t} 0+\mathrm{t}^{*}\right)$ : It takes 1 for the year after WTO accession, and continues to be 1 for the rest of the sample points.

Control Group: Developing country GATT members. Robust standard errors are (in parentheses) adjusted for clustering in all country.

*** implies significance at the 1 per cent level; ${ }^{* *}$ at the 5 per cent level; and ${ }^{*}$ at the 10 per cent level.

Source: The ICRG Index is from PRS Group ICRG database, WTO accession year is from WTO accession documents; $\log$ (real GDP per capita) from the World Bank. 
Table A24. Fixed effects - Robustness analysis:

WTO accession impact, dropping outlier countries

\begin{tabular}{|c|c|c|c|c|c|c|c|c|}
\hline & \multicolumn{4}{|c|}{$\begin{array}{c}\text { Dependent variable: } \\
\text { Index of Economic Freedom }\end{array}$} & \multicolumn{4}{|c|}{$\begin{array}{l}\text { Dependent variable: } \\
\text { ICRG Index }\end{array}$} \\
\hline & Col.1 & Col.2 & Col.3 & Col.4 & Col.5 & Col.6 & Col.7 & Col.8 \\
\hline \multirow[t]{2}{*}{ WTO accession year(t) } & $0.147^{* * *}$ & $0.139^{* * *}$ & & & $0.512 * *$ & $0.523^{* * *}$ & & \\
\hline & $(0.043)$ & $(0.047)$ & & & $(0.195)$ & $(0.170)$ & & \\
\hline \multirow[t]{2}{*}{ WTO accession year ( $\mathrm{t} 0)$} & & & $0.063^{* *}$ & $0.084^{* *}$ & & & 0.190 & $0.222^{* *}$ \\
\hline & & & $(0.036)$ & $(0.038)$ & & & $(0.213)$ & $(0.168)$ \\
\hline \multirow[t]{2}{*}{ WTO accession year after $\left(\mathrm{t} 0+\mathrm{t}^{*}\right)$} & & & $0.131^{* *}$ & $0.152^{* * *}$ & & & $0.661^{* * *}$ & $0.643^{* * *}$ \\
\hline & & & $(0.052)$ & $(0.057)$ & & & $(0.195)$ & $(0.057)$ \\
\hline \multirow[t]{2}{*}{$\log \left(\right.$ real GDP per capita) ${ }_{\mathrm{t}-1}$} & $1.098^{* * *}$ & $1.053^{* * *}$ & $1.028^{* * *}$ & $1.037^{* * *}$ & $2.022^{* * *}$ & $2.051^{* * *}$ & $2.209^{* * *}$ & $1.921^{* * *}$ \\
\hline & $(0.173)$ & $(0.233)$ & $(1.324)$ & $(0.237)$ & $(0.463)$ & $(0.579)$ & $(4.664)$ & $(0.577)$ \\
\hline Country effects & Y & Y & Y & Y & Y & Y & Y & Y \\
\hline Year fixed effects & $\mathrm{N}$ & Y & $\mathrm{N}$ & Y & $\mathrm{N}$ & Y & $\mathrm{N}$ & Y \\
\hline Time trend & $\mathrm{N}$ & Y & $\mathrm{N}$ & Y & $\mathrm{N}$ & Y & $\mathrm{N}$ & Y \\
\hline \multirow[t]{2}{*}{ Constant } & $-6.609^{* * *}$ & $-5.206^{* * *}$ & $-6.478^{* * *}$ & $-5.119^{* * *}$ & $-17.497^{* * *}$ & $-15.194^{* * *}$ & -16.910 & $-14.818^{* * *}$ \\
\hline & $(1.269)$ & $(1.627)$ & $(1.324)$ & $(1.654)$ & (3.291) & $(4.006)$ & (3.308) & (3.995) \\
\hline Outlier countries & \multicolumn{8}{|c|}{ China and Saudi Arabia } \\
\hline \#Observations & 887 & 887 & 887 & 887 & 762 & 762 & 762 & 762 \\
\hline \#Countries & 96 & 96 & 96 & 96 & 78 & 78 & 78 & 78 \\
\hline R-squared & 0.445 & 0.446 & 0.443 & 0.447 & 0.303 & 0.316 & 0.305 & 0.317 \\
\hline F-statistics & 49.24 & 11.24 & 32.55 & 10.24 & 27.20 & 23.28 & 27.37 & 24.26 \\
\hline
\end{tabular}

Notes: See previous tables. 


\section{POLICY ISSUES IN INTERNATIONAL TRADE AND COMMODITIES}

No. 1 Erich Supper, Is there effectively a level playing field for developing country exports?, 2001, 138 p. Sales No. E.00.II.D.22.

No. 2 Arvind Panagariya, E-commerce, WTO and developing countries, 2000, 24 p. Sales No. E.00. II.D.23.

No. 3 Joseph Francois, Assessing the results of general equilibrium studies of multilateral trade negotiations, 2000, 26 p. Sales No. E.00.II.D.24.

No. 4 John Whalley, What can the developing countries infer from the Uruguay Round models for future negotiations?, 2000, 29 p. Sales No. E.00.II.D.25.

No. 5 Susan Teltscher, Tariffs, taxes and electronic commerce: Revenue implications for developing countries, 2000, 57 p. Sales No. E.00.II.D.36.

No. 6 Bijit Bora, Peter J. Lloyd, Mari Pangestu, Industrial policy and the WTO, 2000, 47 p. Sales No. E.00.II.D.26.

No. 7 Emilio J. Medina-Smith, Is the export-led growth hypothesis valid for developing countries? A case study of Costa Rica, 2001, 49 p. Sales No. E.01.II.D.8.

No. 8 Christopher Findlay, Service sector reform and development strategies: Issues and research priorities, 2001, 24 p. Sales No. E.01.II.D.7.

No. 9 Inge Nora Neufeld, Anti-dumping and countervailing procedures-Use or abuse? Implications for developing countries, 2001, 33 p. Sales No. E.01.II.D.6.

No. 10 Robert Scollay, Regional trade agreements and developing countries: The case of the Pacific Islands' proposed free trade agreement, 2001, 45 p. Sales No. E.01.II.D.16.

No. 11 Robert Scollay and John Gilbert, An integrated approach to agricultural trade and development issues: Exploring the welfare and distribution issues, 2001, 43 p. Sales No. E.01.II.D.15.

No. 12 Marc Bacchetta and Bijit Bora, Post-Uruguay round market access barriers for industrial products, 2001, 50 p. Sales No. E.01.II.D.23.

No. 13 Bijit Bora and Inge Nora Neufeld, Tariffs and the East Asian financial crisis, 2001, 30 p. Sales No. E.01.II.D.27.

No. 14 Bijit Bora, Lucian Cernat, Alessandro Turrini, Duty and quota-free access for LDCs: Further evidence from CGE modelling, 2002, 130 p. Sales No. E.01.II.D.22.

No. 15 Bijit Bora, John Gilbert, Robert Scollay, Assessing regional trading arrangements in the AsiaPacific, 2001, 29 p. Sales No. E.01.II.D.21. 
No. 16 Lucian Cernat, Assessing regional trade arrangements: Are South-South RTAs more trade diverting?, 2001, 24 p. Sales No. E.01.II.D.32.

No. 17 Bijit Bora, Trade related investment measures and the WTO: 1995-2001, 2002.

No. 18 Bijit Bora, Aki Kuwahara, Sam Laird, Quantification of non-tariff measures, 2002, 42 p. Sales No. E.02.II.D.8.

No. 19 Greg McGuire, Trade in services - Market access opportunities and the benefits of liberalization for developing economies, 2002, 45 p. Sales No. E.02.II.D.9.

No. 20 Alessandro Turrini, International trade and labour market performance: Major findings and open questions, 2002, 30 p. Sales No. E.02.II.D.10.

No. 21 Lucian Cernat, Assessing south-south regional integration: Same issues, many metrics, 2003, 32 p. Sales No. E.02.II.D.11.

No. 22 Kym Anderson, Agriculture, trade reform and poverty reduction: Implications for SubSaharan Africa, 2004, 30 p. Sales No. E.04.II.D.5.

No. 23 Ralf Peters and David Vanzetti, Shifting sands: Searching for a compromise in the WTO negotiations on agriculture, 2004, 46 p. Sales No. E.04.II.D.4.

No. 24 Ralf Peters and David Vanzetti, User manual and handbook on Agricultural Trade Policy Simulation Model (ATPSM), 2004, 45 p. Sales No. E.04.II.D.3.

No. 25 Khalil Rahman, Crawling out of snake pit: Special and differential treatment and postCancun imperatives, 2004.

No. 26 Marco Fugazza, Export performance and its determinants: Supply and demand constraints, 2004, 57 p. Sales No. E.04.II.D.20.

No. 27 Luis Abugattas, Swimming in the spaghetti bowl: Challenges for developing countries under the "New Regionalism", 2004, 30 p. Sales No. E.04.II.D.38.

No. 28 David Vanzetti, Greg McGuire and Prabowo, Trade policy at the crossroads - The Indonesian story, 2005, 40 p. Sales No. E.04.II.D.40.

No. 29 Simonetta Zarrilli, International trade in GMOs and GM products: National and multilateral legal frameworks, 2005, 57 p. Sales No. E.04.II.D.41.

No. 30 Sam Laird, David Vanzetti and Santiago Fernández de Córdoba, Smoke and mirrors: Making sense of the WTO industrial tariff negotiations, 2006, Sales No. E.05.II.D.16.

No. 31 David Vanzetti, Santiago Fernandez de Córdoba and Veronica Chau, Banana split: How EU policies divide global producers, 2005, 27 p. Sales No. E.05.II.D.17.

No. 32 Ralf Peters, Roadblock to reform: The persistence of agricultural export subsidies, 2006, 43 p. Sales No. E.05.II.D.18.

No. 33 Marco Fugazza and David Vanzetti, A South-South survival strategy: The potential for trade among developing countries, 2006, 25 p. 
No. 34 Andrew Cornford, The global implementation of Basel II: Prospects and outstanding problems, 2006, $30 \mathrm{p}$.

No. 35 Lakshmi Puri, IBSA: An emerging trinity in the new geography of international trade, 2007, $50 \mathrm{p}$.

No. 36 Craig VanGrasstek, The challenges of trade policymaking: Analysis, communication and representation, 2008, $45 \mathrm{p}$.

No. 37 Sudip Ranjan Basu, A new way to link development to institutions, policies and geography, 2008, 50 p.

No. 38 Marco Fugazza and Jean-Christophe Maur, Non-tariff barriers in computable general equilibrium modelling, 2008, $25 \mathrm{p}$.

No. 39 Alberto Portugal-Perez, The costs of rules of origin in apparel: African preferential exports to the United States and the European Union, 2008, 35 p.

No. 40 Bailey Klinger, Is South-South trade a testing ground for structural transformation?, 2009, $30 \mathrm{p}$.

No. 41 Sudip Ranjan Basu, Victor Ognivtsev and Miho Shirotori, Building trade-relating institutions and WTO accession, 2009, $50 \mathrm{p}$. 


\section{United Nations Publications}

All orders from North America, Latin America, the Caribbean and Asia and the Pacific should be sent to:

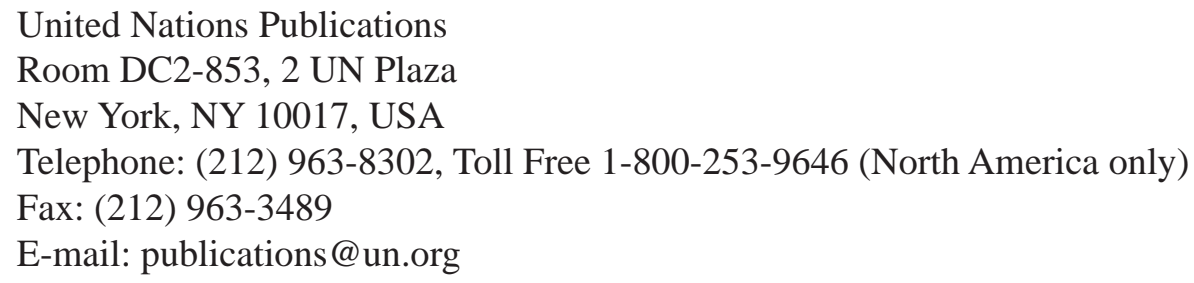

Customers in Europe, Africa and the Middle East should send their orders to:

Section des Ventes et Commercialisation

Bureau E-4, CH-1211

Geneva 10, Switzerland

Telephone: 41 (22) 917-2613/2614

Fax: 41 (22) 917-0027

E-mail: unpubli@unog.ch

For further information, please visit: http://www.unctad.org/tab 


\section{QUESTIONNAIRE}

UNCTAD Study series on

\section{POLICY ISSUES IN INTERNATIONAL TRADE AND COMMODITIES}

(Study series no. 41: Building trade-relating institutions and WTO accession)

\section{Readership Survey}

Since 1999, the Trade Analysis Branch of the Division on International Trade in Goods and Services, and Commodities of UNCTAD has been carrying out policy-oriented analytical work aimed at improving the understanding of current and emerging issues in international trade and development. In order to improve the quality of the work of the Branch, it would be useful to receive the views of readers on this and other similar publications. It would therefore be greatly appreciated if you could complete the following questionnaire and return to:

Trade Analysis Branch, DITC

United Nations Conference on Trade and Development

Palais des Nations, Rm. E-8076

CH-1211 Geneva 10, Switzerland

(fax: +41 22917 0044; e-mail: tab@unctad.org)

1. Name and address of respondent (optional):

2. Which of the following describes your area of work?

\section{Government}

Private enterprise institution

International organization

Not-for-profit organization
Public enterprise

Academic or research

Media

Other (specify)

3. In which country do you work?

4. Did you find this publication $\square$ Very useful $\square$ Of some use $\square$ Little use to your work?

5. What is your assessment of the contents of this publication?
$\square$ Excellent
$\square$ Good
$\square$ Adequate
$\square$ Poor

6. Other comments: 